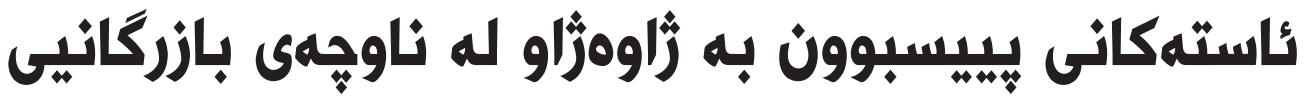

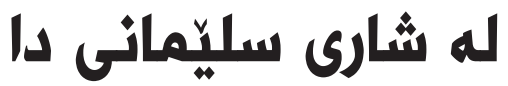

مهدى هادى احمد - خويَندكارى ماستهر

به شى جوگرافيا-كوّليّزَى زانستهمروقايهتيه كان-زانكوّى سليّمانى/ ههريّمى كوردستان-عيّراق qi.ude.lusvinu@dehsaR.nawrihs

ي ى د.شيروان عمر رهشيد

به شى جوكَرافيا-كوّليّزَى زانستهمروّايهتيه كان-زانكوّى سليّمانى/ ههريّمى كوردستان-عيّراق qi.ude.lusvinu@210060.idah

يوخته

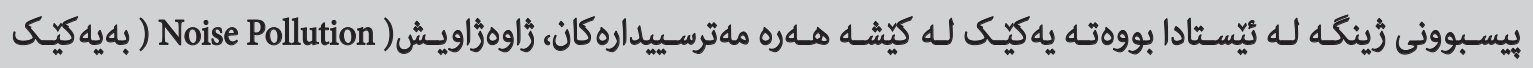

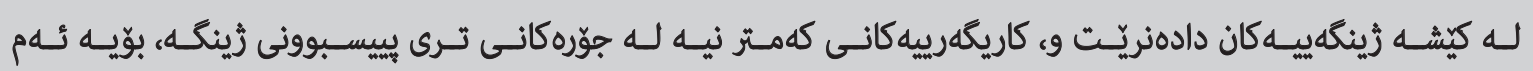

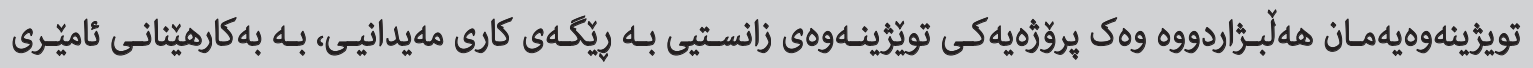

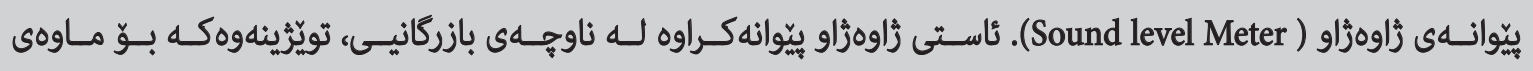

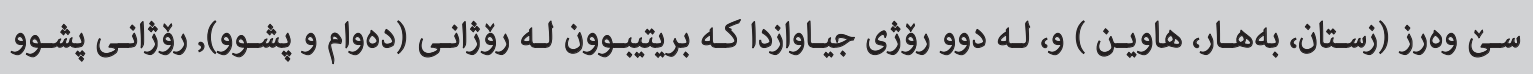

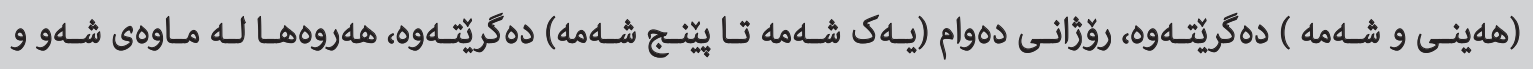

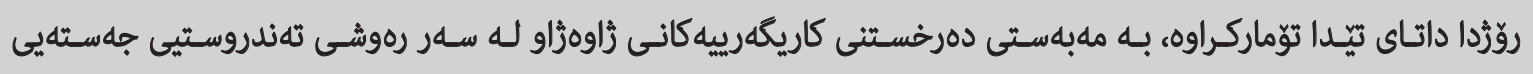

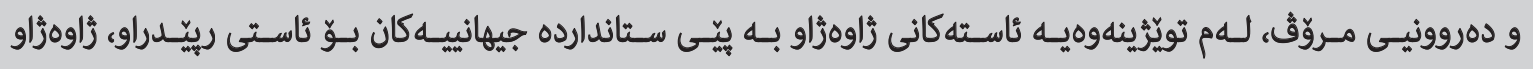

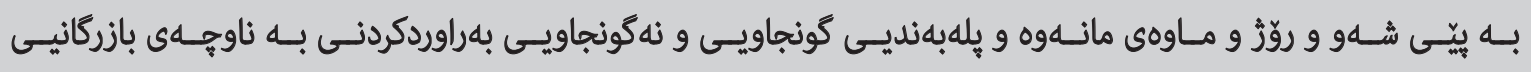

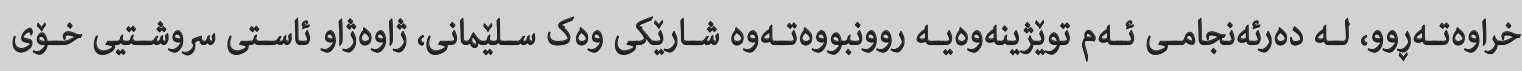

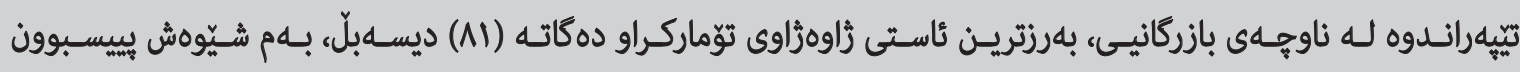

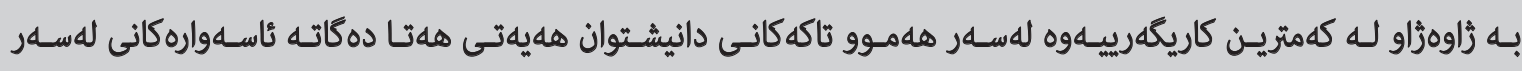

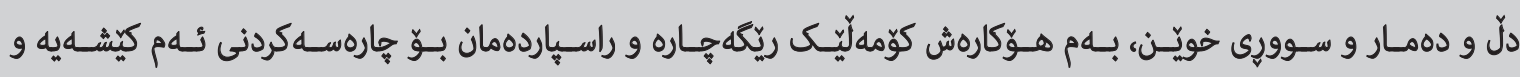

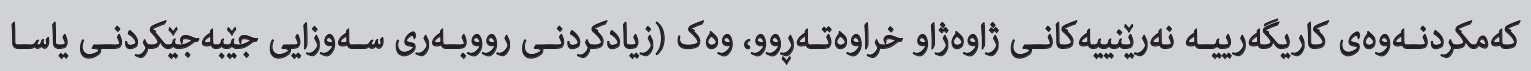

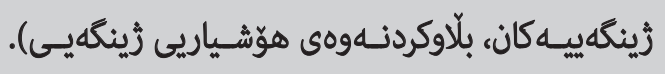

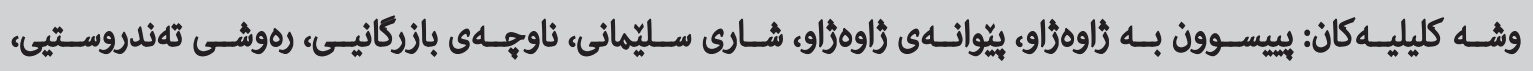
كاريكهريسى و هارهسـهـ ورن. 
بِيّشه كيى

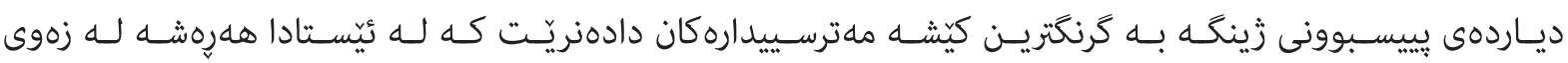

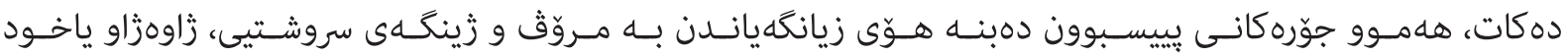

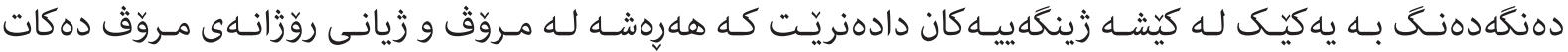

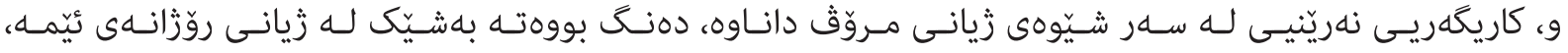

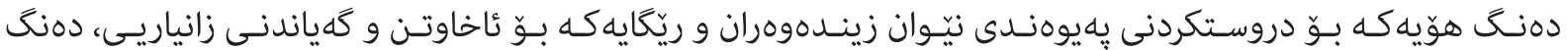

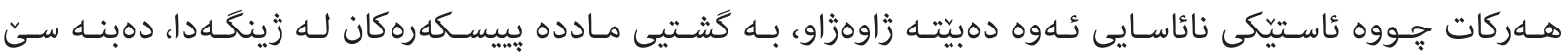

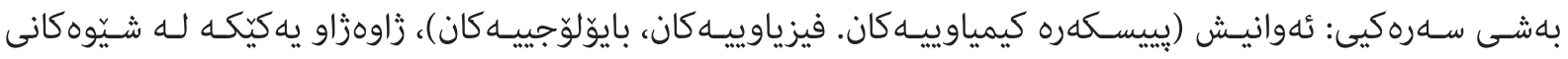

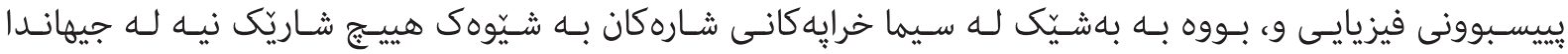

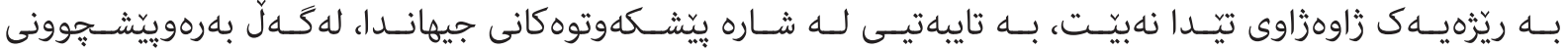

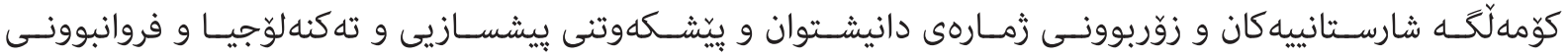

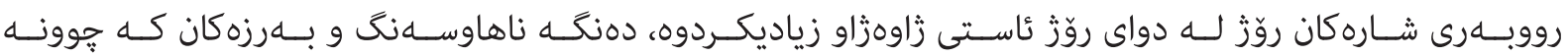

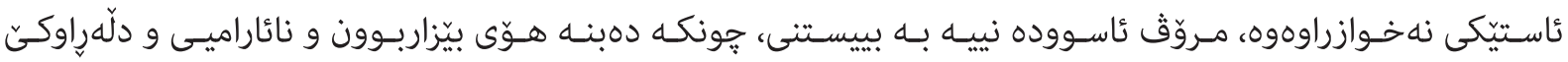

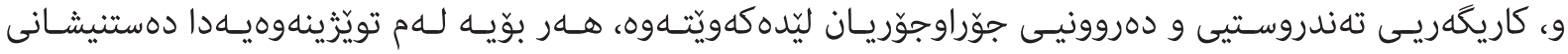

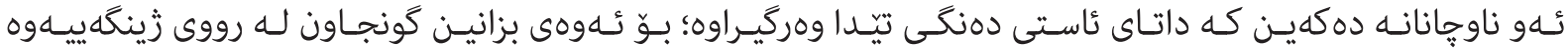

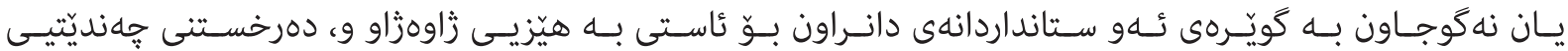
كاريكهرييـان.

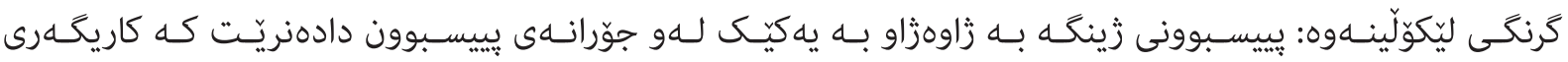

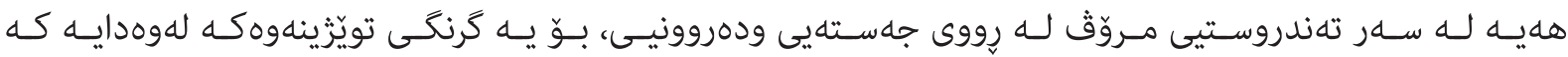

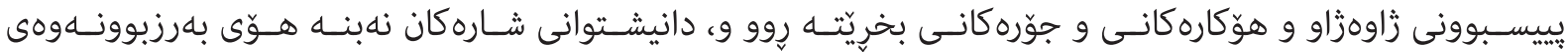

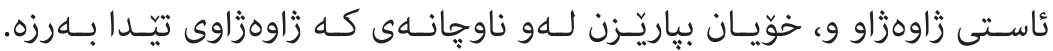

ئامانجى تويَزينهوه: ا-جياكردنهوهى ئاسته كانى بييسبوونى زاوهزاو له ناوجهلى بازركانيى بهيّيى شويّن و كات له شارى سليّمانيدا. r-شيكردنهوهى يِييسبوونى زاوهزاو و زانينى ليّكهوته نهريّنييه كانيى و جِوّنيهتى جارهسهركردنيى. كيّشهى تويَزَينهوه:

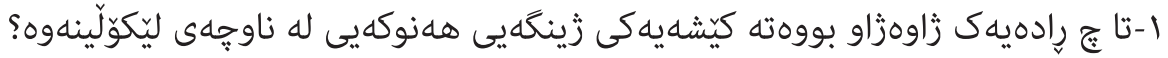

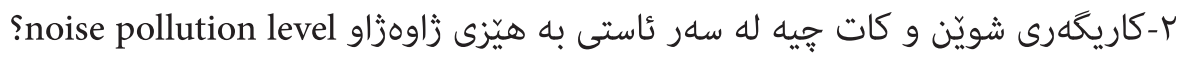

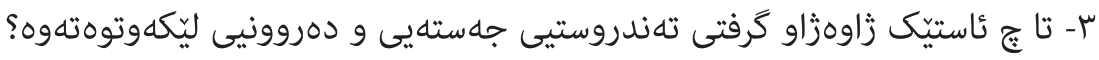
ميتوّدى تويَزَينهوه:

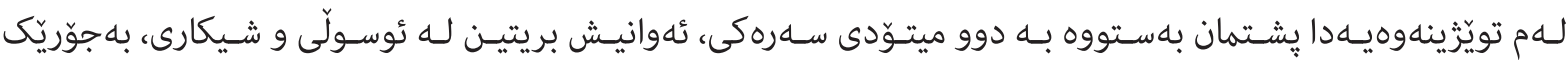

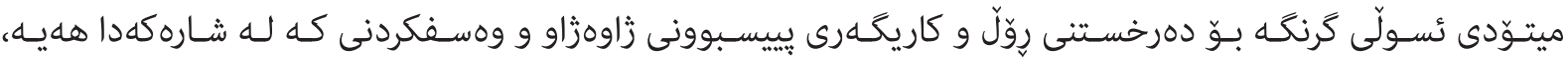

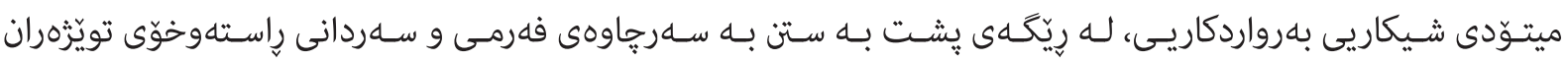




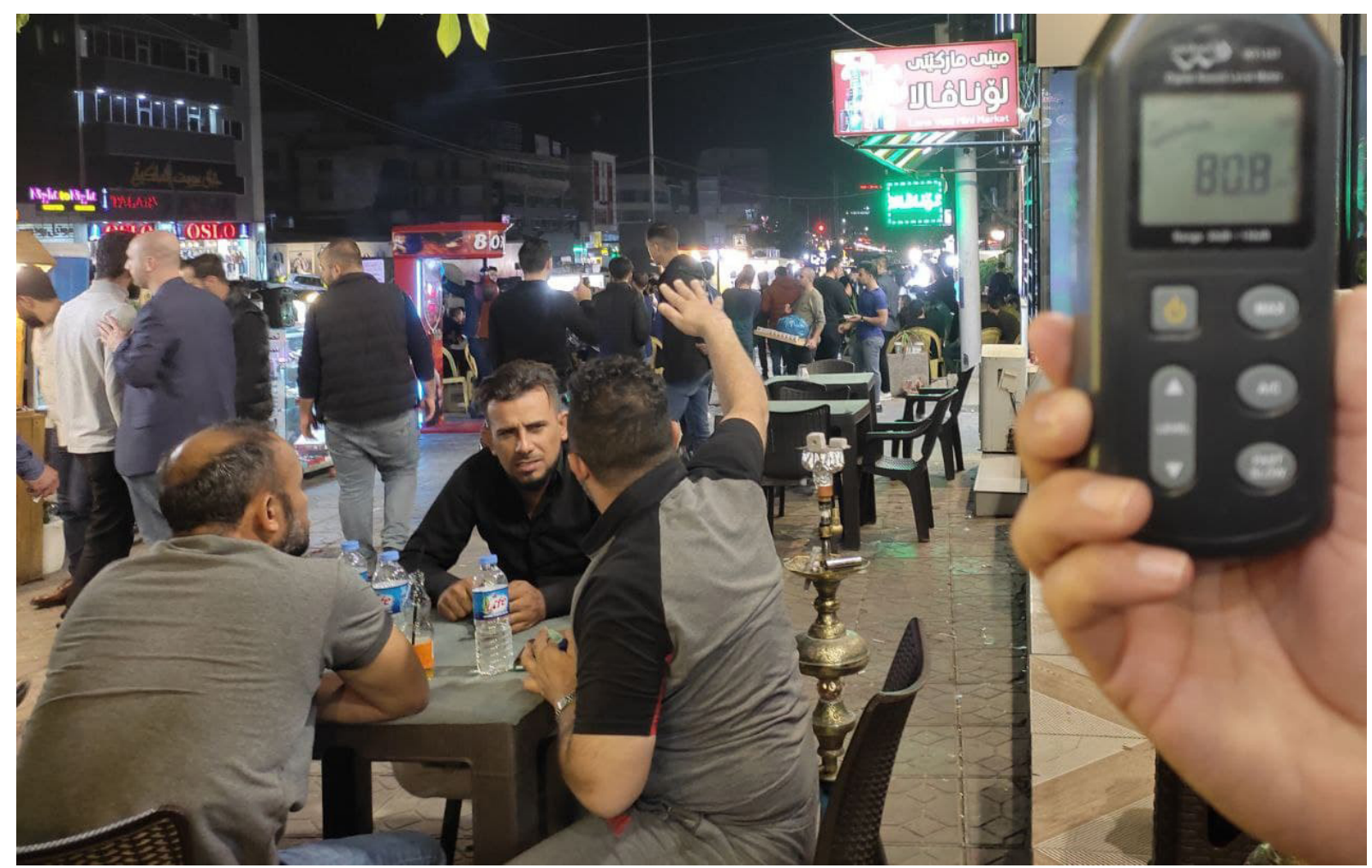

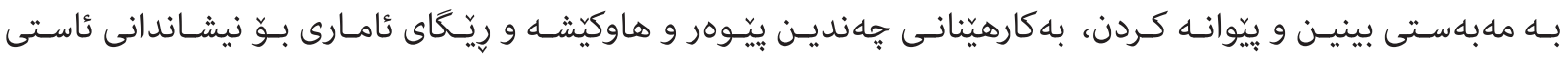

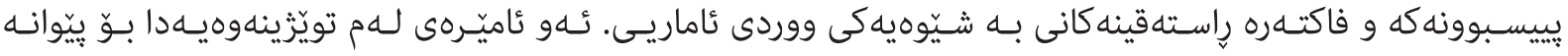

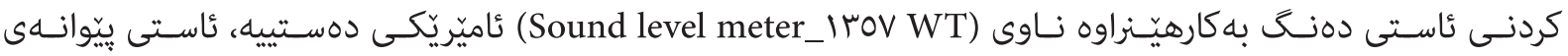

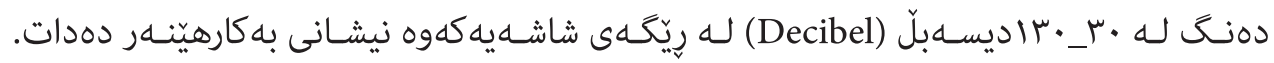
ويّنهى (1) ناوجهى بازركانى ناوجهركهى (جههقى)

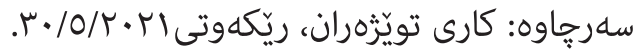
كريمانهى تويَزَينهوه:

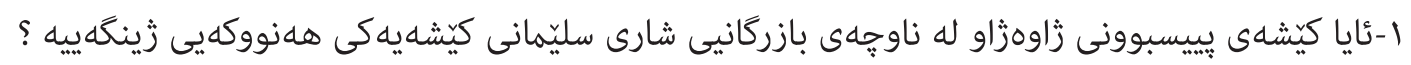

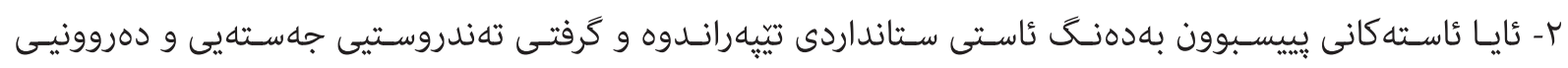
جوّراوجـوّرى ليّكهوتووهتـهوه؟

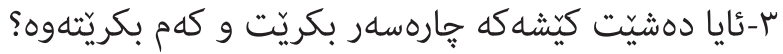

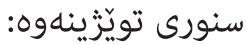
سنورى شوينى: شارى سليّمانيى

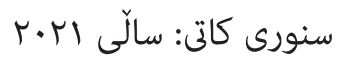

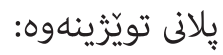

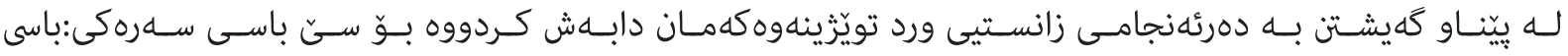

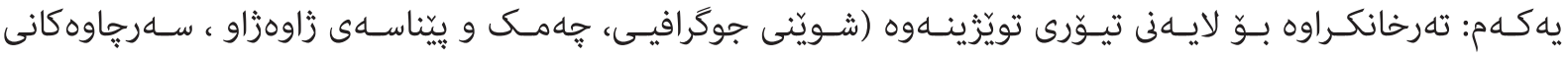


.

باسى دووهم: شيكردنهوهى ئاستى يِييسبوونى زاوهزاو و هلّسهنكَاندنى يِيّوانهى هيّزى زاوهزاو به يِيَى ستانداردهكان.

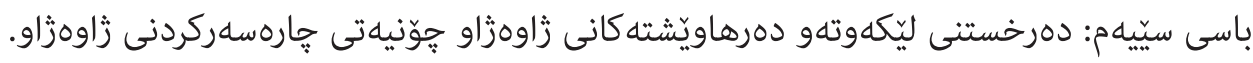
باسى يهكهم: لايهنى تيوّرى تويَّزينهوه

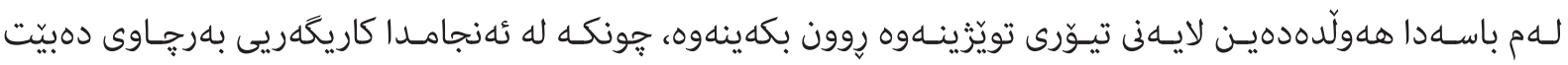

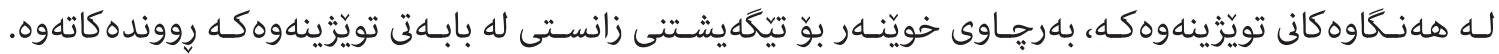

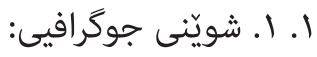

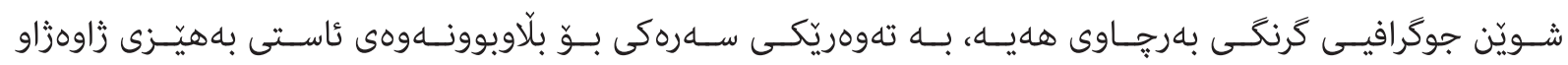

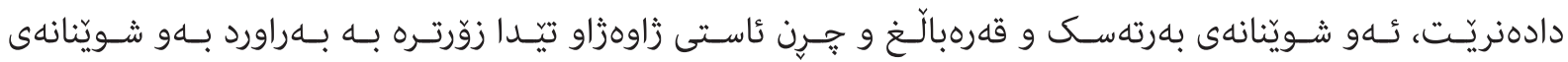

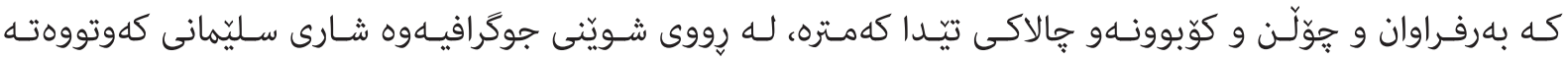

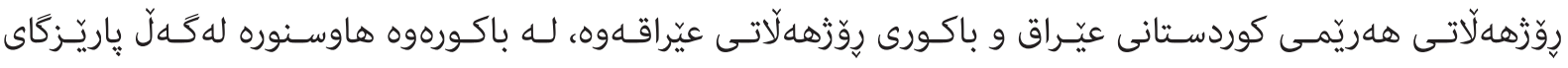

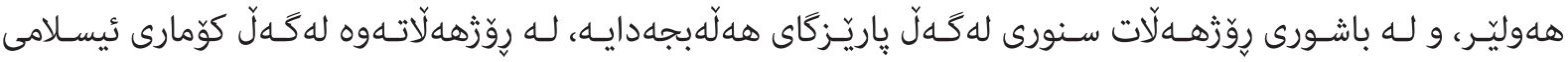

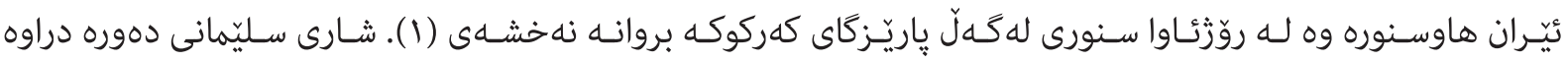

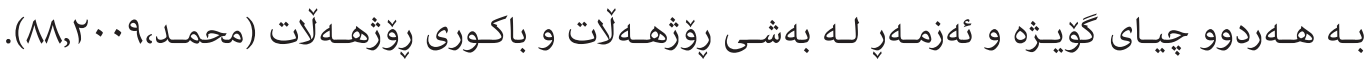

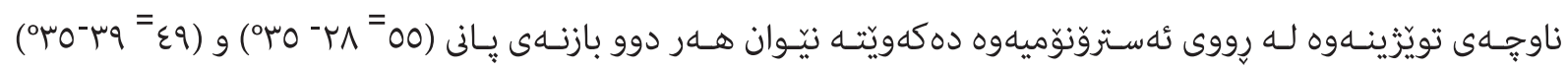

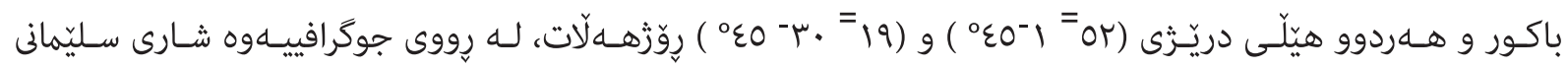

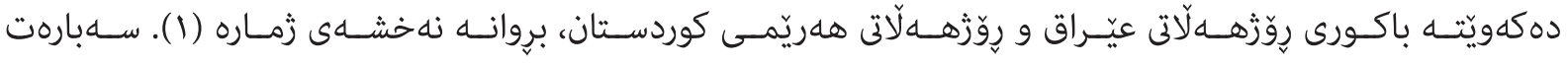

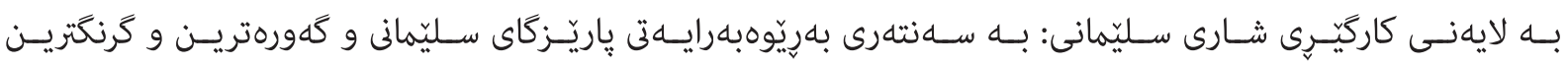

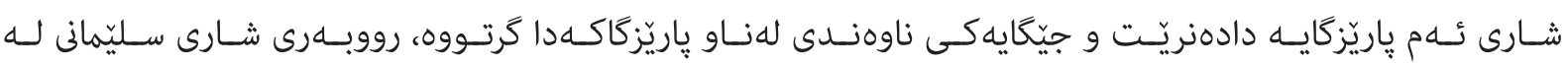

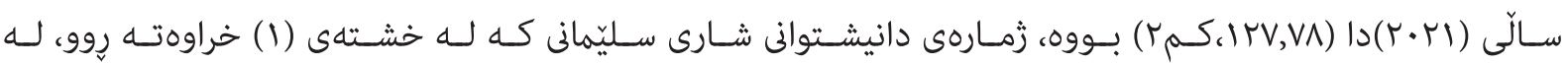

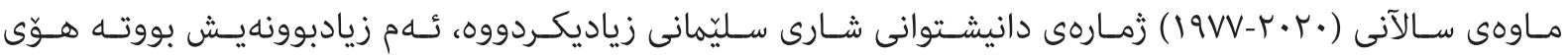

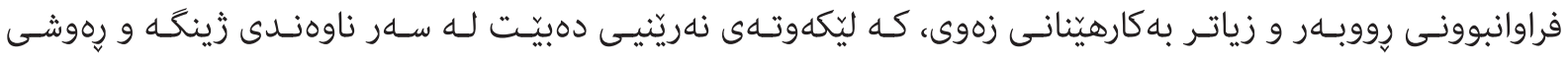

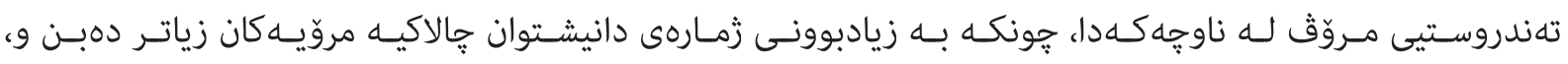

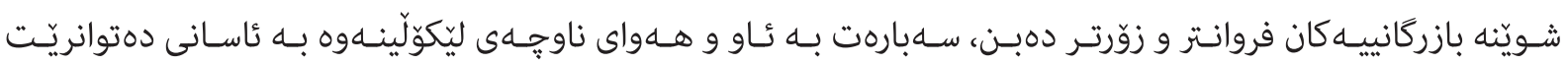

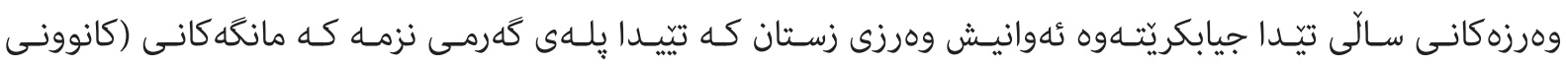

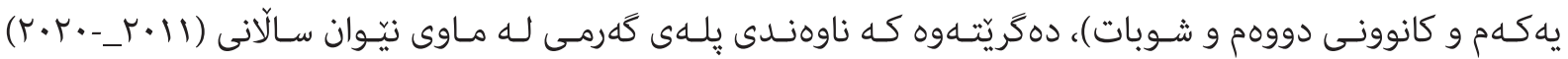

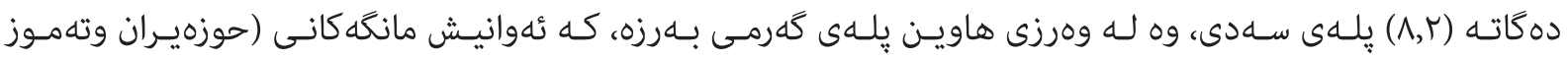

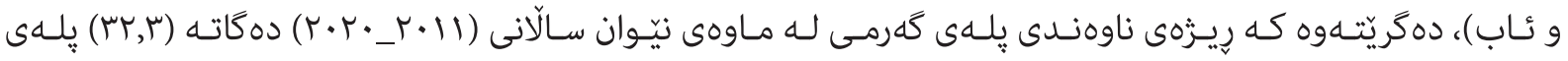

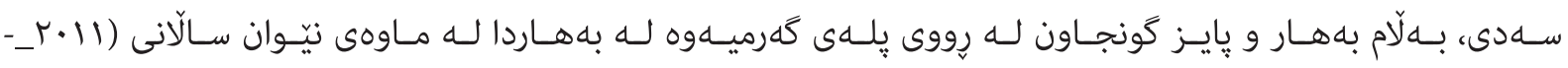

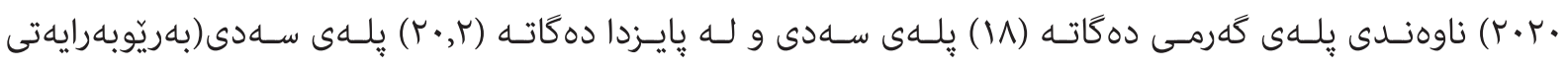

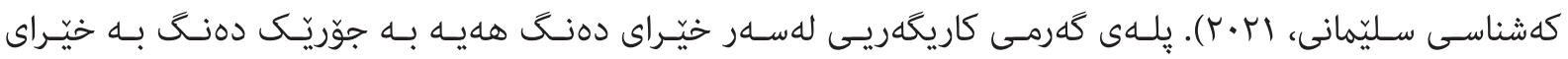

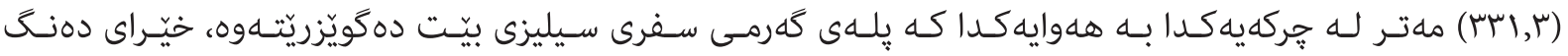




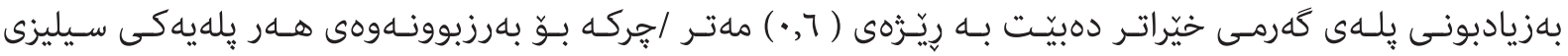

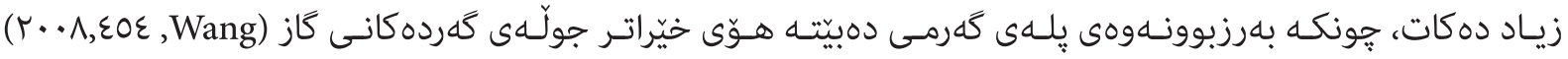

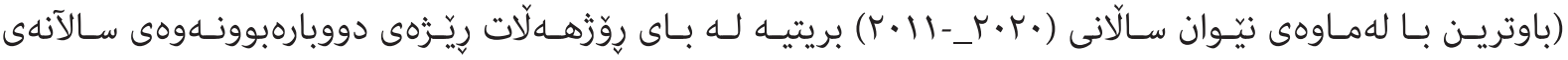

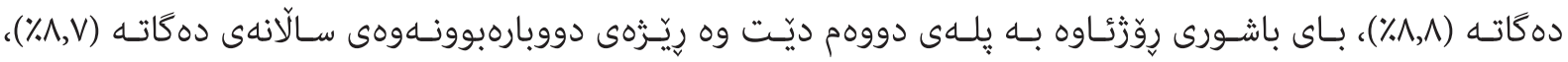

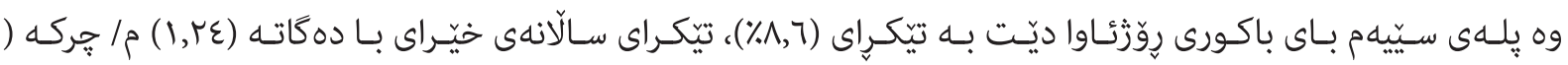

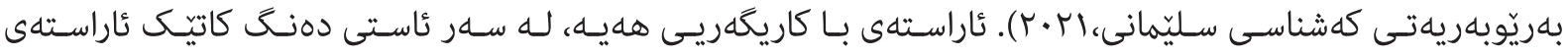

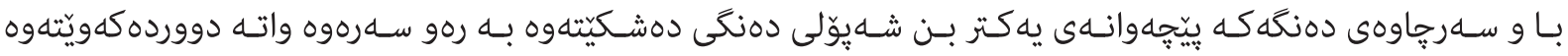

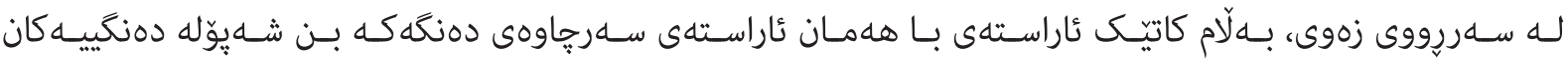

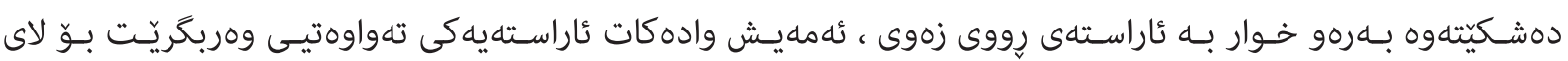

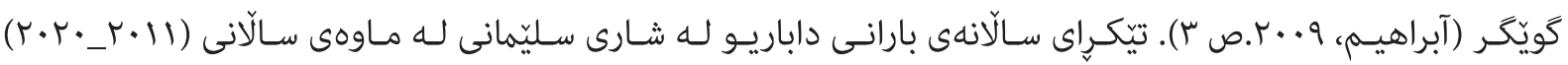

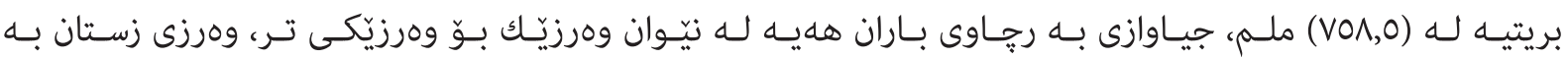

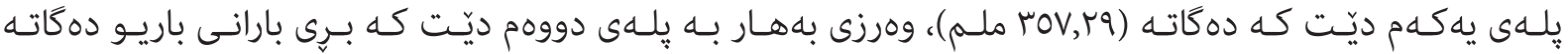

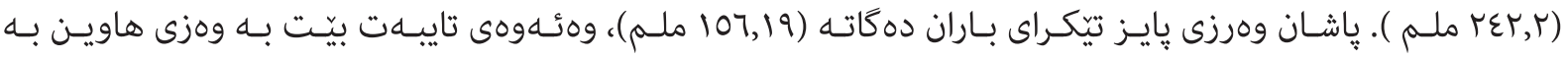

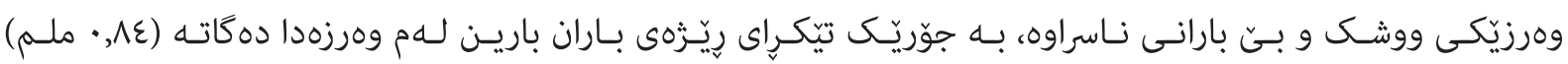

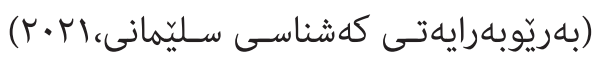

خشتهى زماره(1) (1) (1) (1)

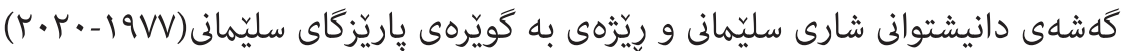

\begin{tabular}{|c|c|c|c|c|}
\hline 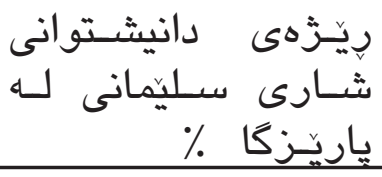 & ثِماريّزَى دانى سليشّانى & زيادبوونى سالانه & رانيثتوانى & سال \\
\hline$r_{0,0}$ & $79.00 \mathrm{~V}$ & - & IVO\&IT & (1) $19 V V$ \\
\hline r^,r & 901VKr & $V, 0$ & rาE. 97 & (r) $) 9 \wedge V$ \\
\hline$\varepsilon 0,0$ & 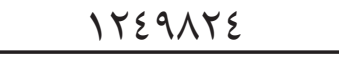 & r & 079114 & ${ }^{(r)} r \ldots r$ \\
\hline MY,Y & MYOMII & $\cdot, \varepsilon Y$ & ONATOY & (E) $Y \cdot 1$. \\
\hline 56.0 & *** I TrV. AV & r & $* 9111 V 6$ & ${ }^{(0)} r \cdot r^{-}$ \\
\hline
\end{tabular}

(19VV، 19V، نتائج التعداد العام للسكان.

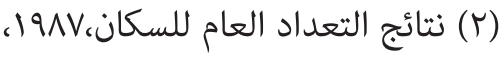

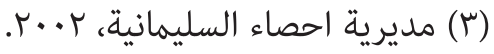

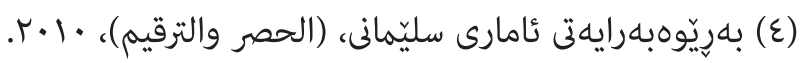

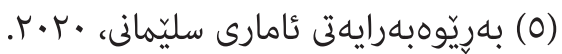

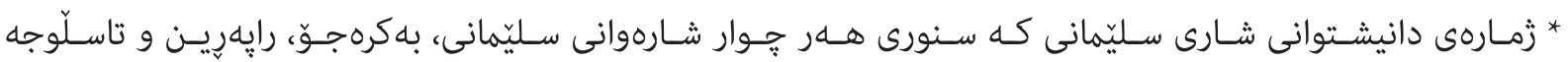
.

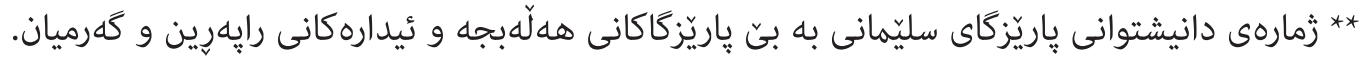




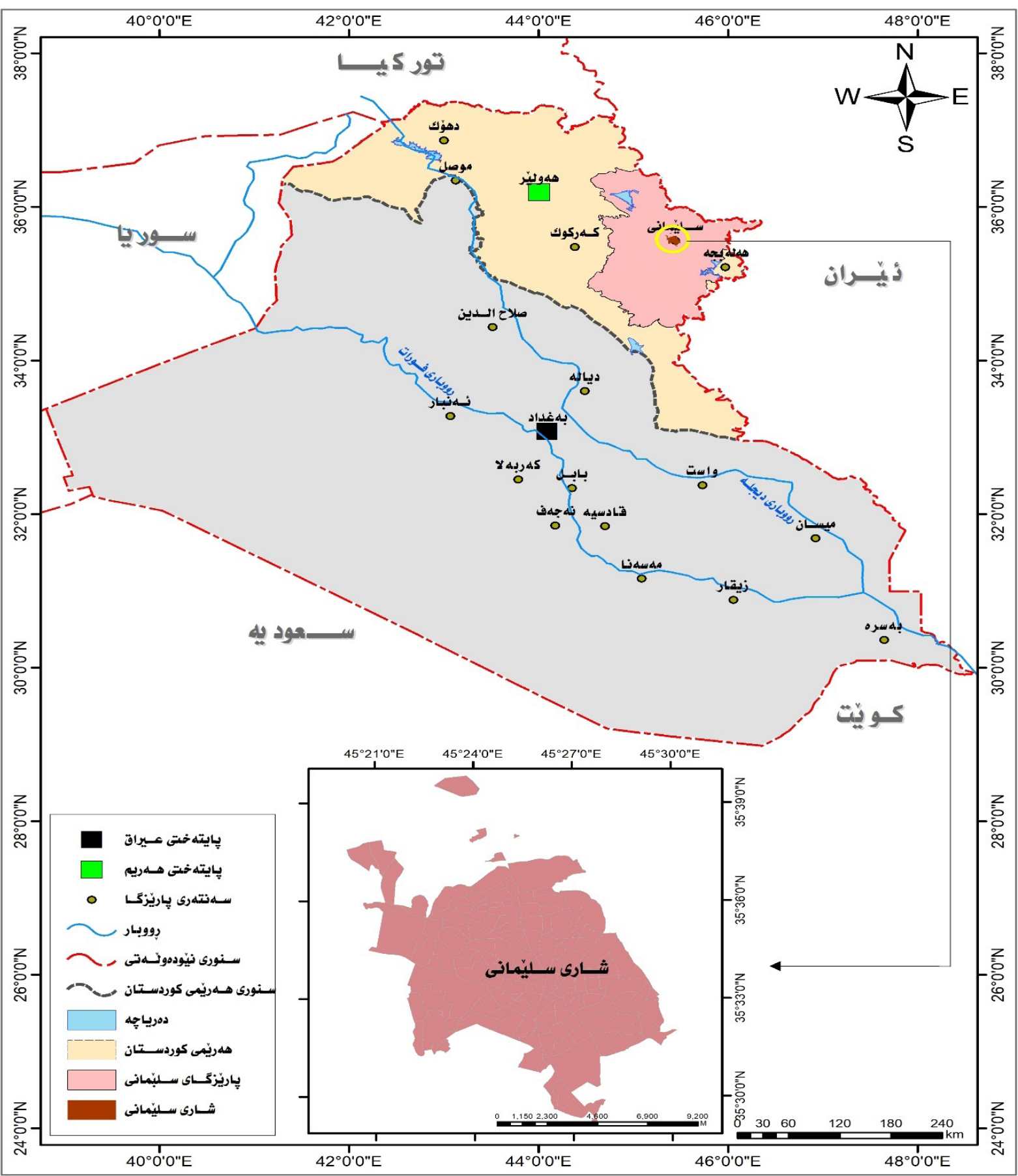

سهرجاوه: بهريّوهبهرايهتى ئامارى سليّمانى، الr.r.

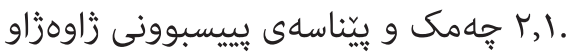

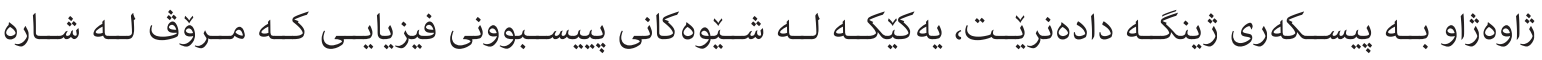

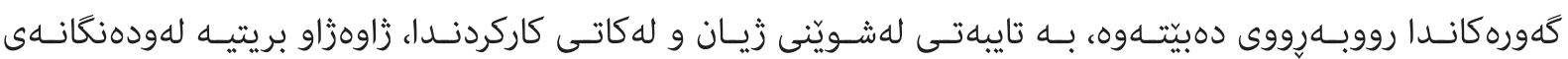

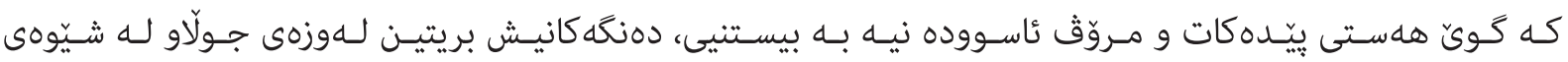

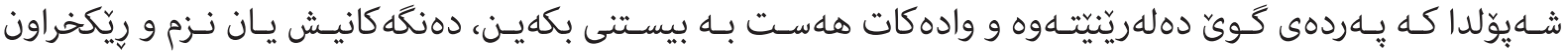

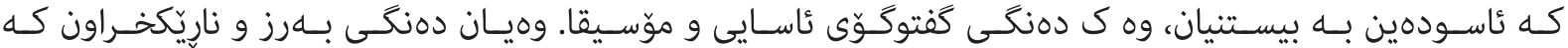




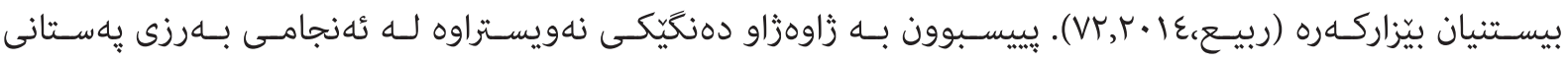

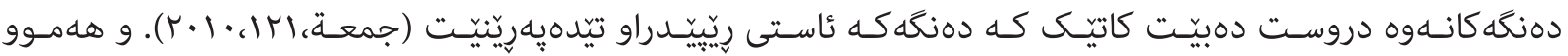

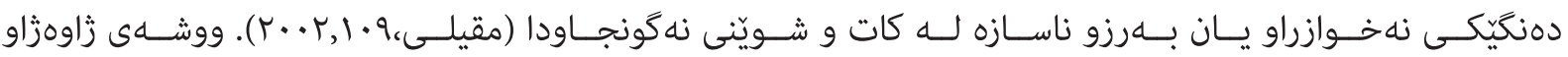

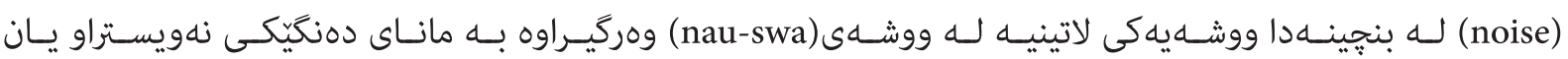

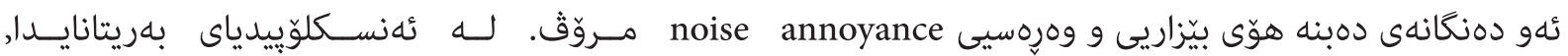

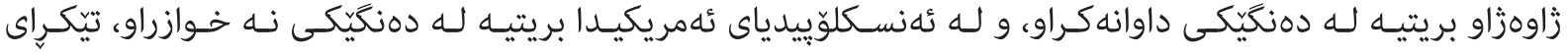

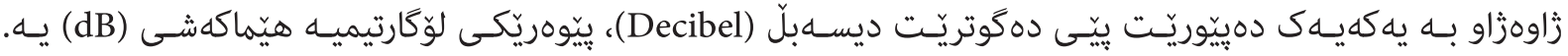

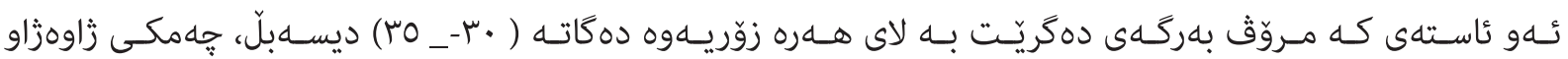

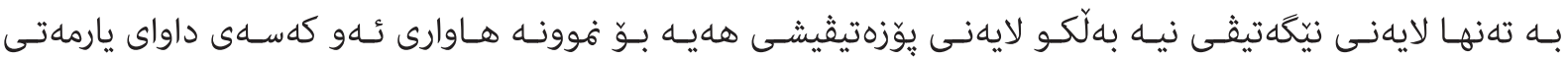

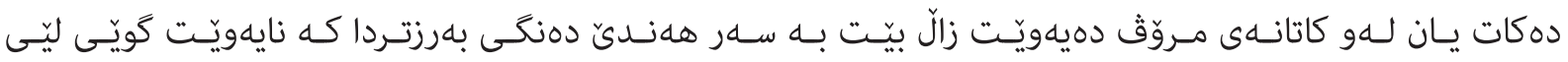

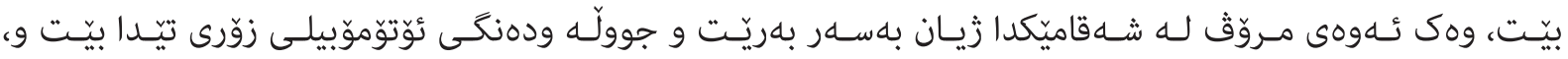

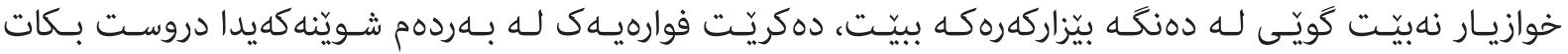

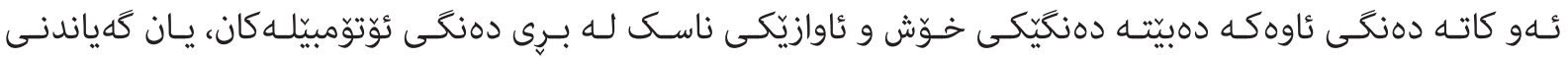

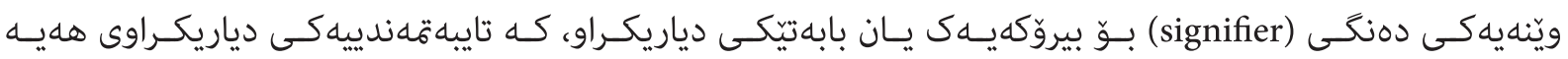

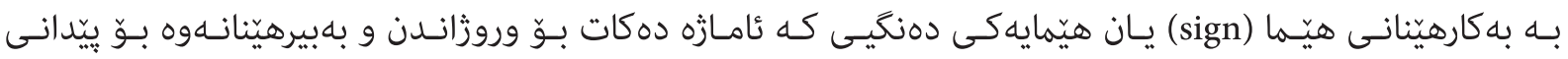

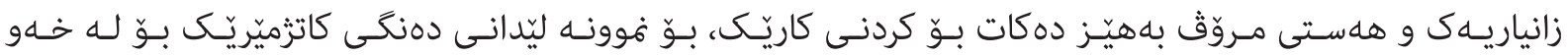

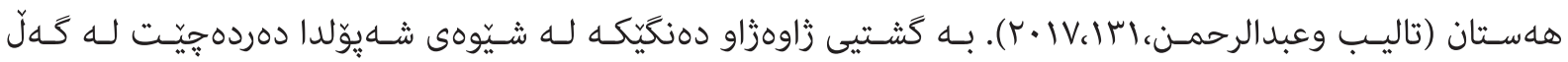

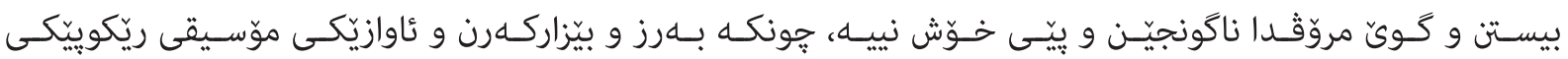

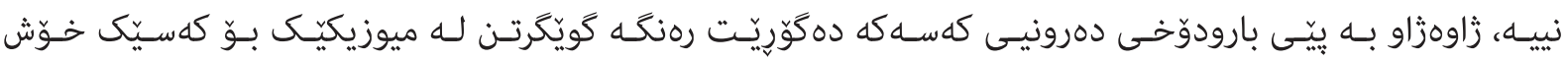

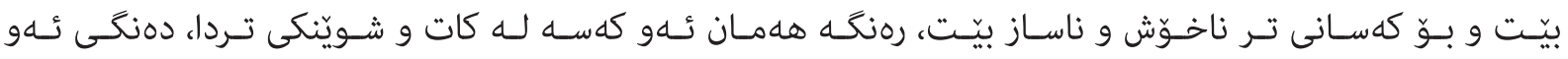

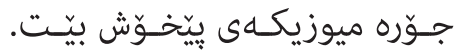

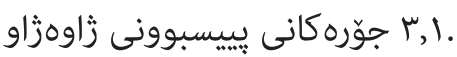

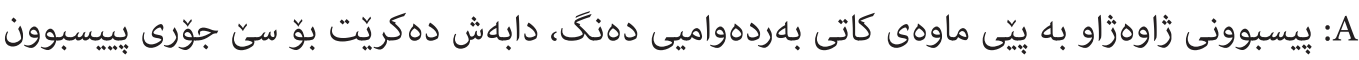

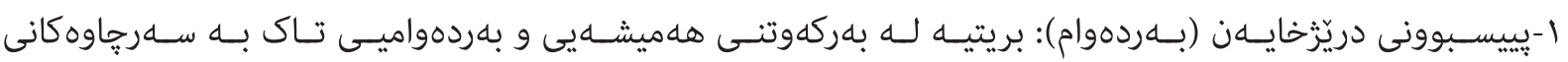

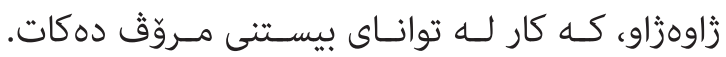

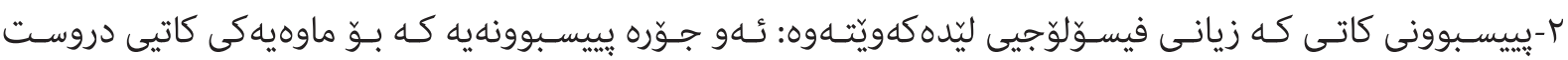

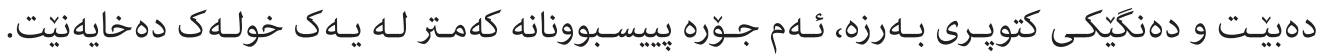

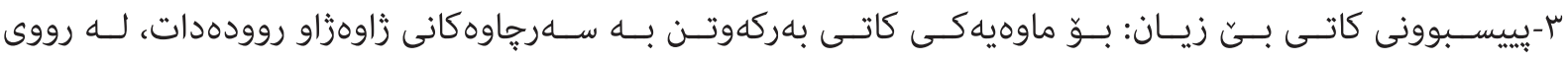

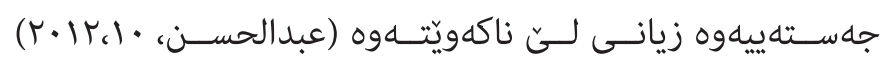

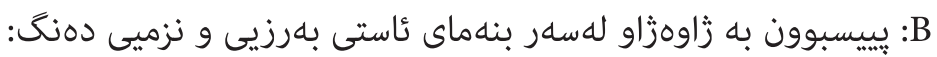

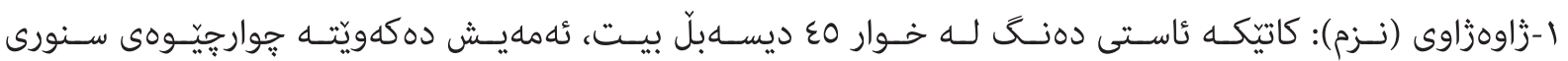
ياريّـزراوى تهندروســييهوه. 


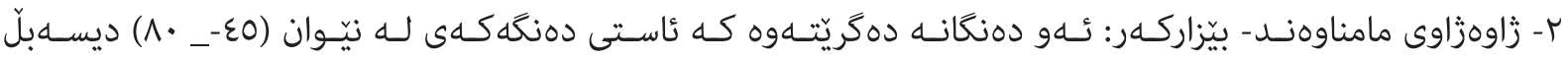

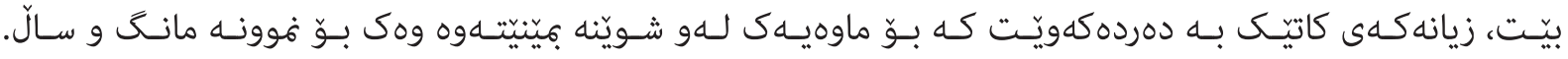

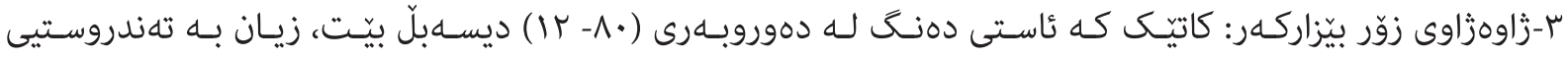

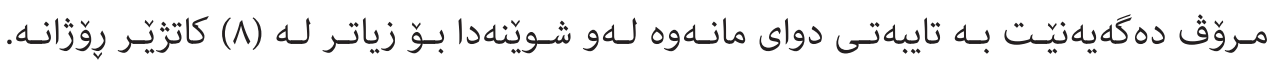

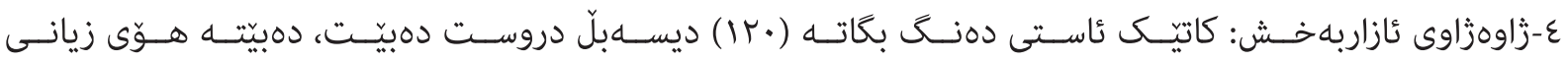
جلسـتهيى (الحسـن،

1, اع. سهرجاوهكانى زاوهزاو: به شيّوهيهكى كَشتيى سهرجاوه كانى زاوهزاو دهكريّت به دوو بهشهوه

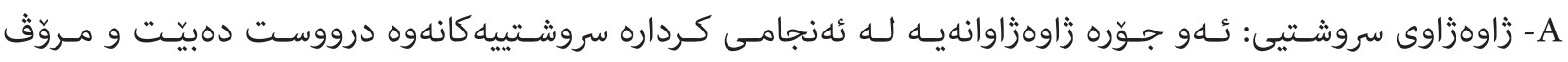

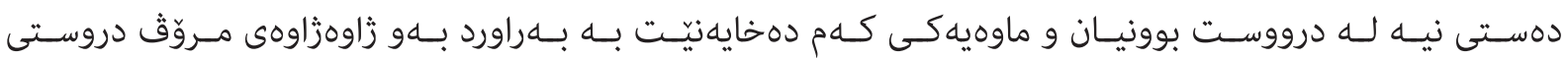

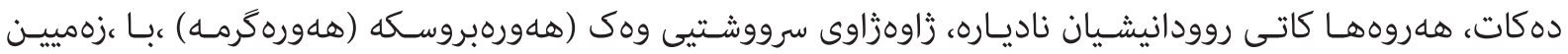

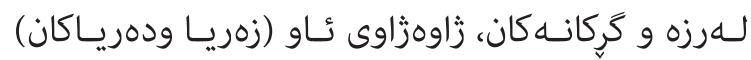

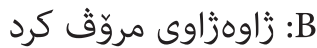

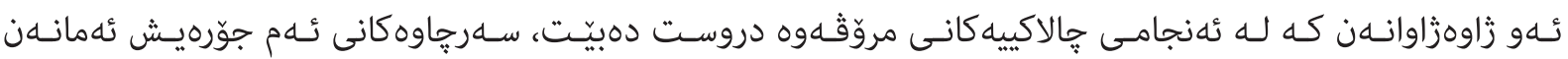

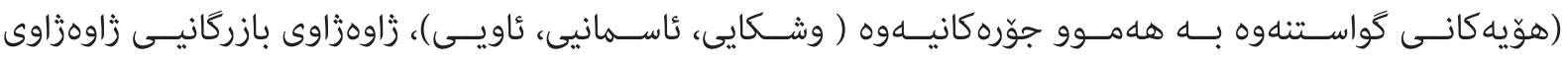
دامـهزراوه يِيشهسـازييه كان، زاوهزاوى كوّمهلآيهتيـى، زاوهزاوى بيناسـازيى و بونيادنـان، زاوهزاوى ئاميّـره كارهباييـه كان

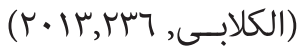

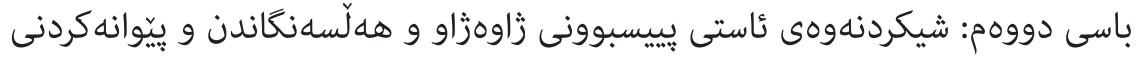

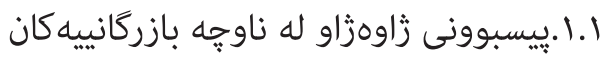

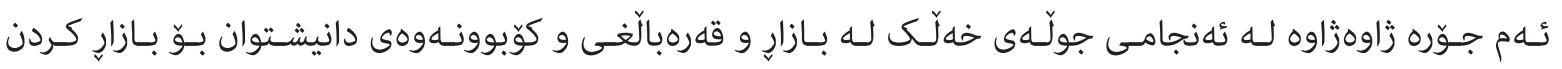

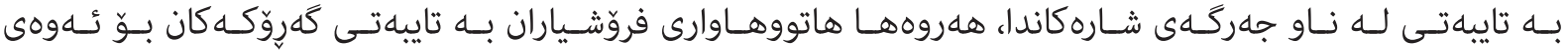

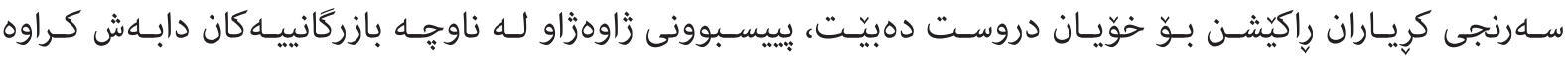

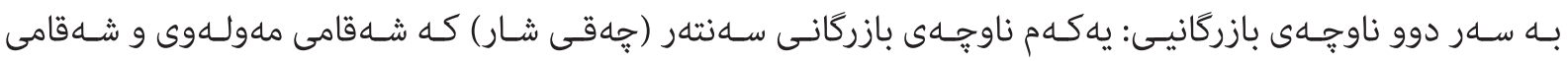

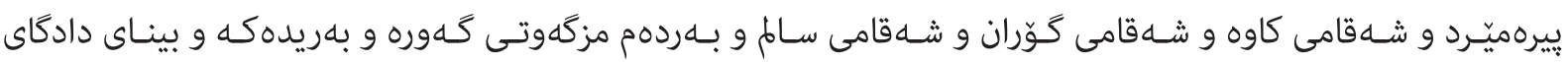

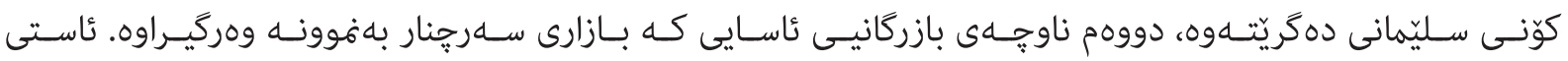

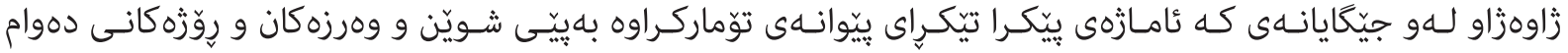

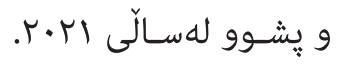

خشتهى زماره (r) تيّكراى ئاستى زاوهزاو له ناوجهى بازركانيى بهَّويَرهى شهو و روّز و له وهرزى (زستان، بههار، 
dB هاوين) بهيهكهى

\begin{tabular}{|c|c|c|c|c|c|c|c|c|c|c|}
\hline \multicolumn{3}{|c|}{ وهرزى هاوين } & \multicolumn{3}{|c|}{ وهرزى بههار } & \multicolumn{3}{|c|}{ وهرزى زستان } & \multirow[t]{2}{*}{ رِّ } & \multirow{2}{*}{ 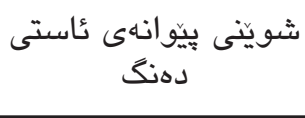 } \\
\hline تيكرا & شاهو & روّذ & تيكرا & شاهو & روّذ & تيكرا & شاهو & روّذ & & \\
\hline 75 & 74 & Vo & 75 & 72 & 78 & 72 & 69 & 75 & بشوو & \multirow{2}{*}{ ناوجهاءى بازركانيى ناوكى } \\
\hline 74 & 71 & VV & 77 & 73 & 81 & 75 & 68 & 81 & لدهوام & \\
\hline 65 & 69 & 7. & 66 & 66 & 66 & 65 & 65 & 64 & يشوو & \multirow{2}{*}{ 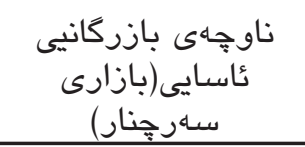 } \\
\hline 65 & $67^{\circ}$ & זר & 68 & 65 & 70 & 66 & 63 & 68 & لدهوام & \\
\hline 75 & $v_{r}$ & VI & 77 & $V r$ & 80 & 74 & 79 & 78 & 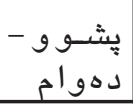 & 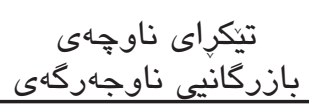 \\
\hline 65 & 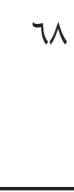 & $\pi r$ & 68 & 77 & 69 & 65 & $7 \varepsilon$ & 66 & ل دهوام و - & 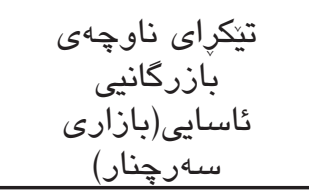 \\
\hline
\end{tabular}

سهرجاوه: كارى تويّزَهران به يُت بهستن به سهردانى مهيدانى بوّ ناوجهى تويَزَينهوه.

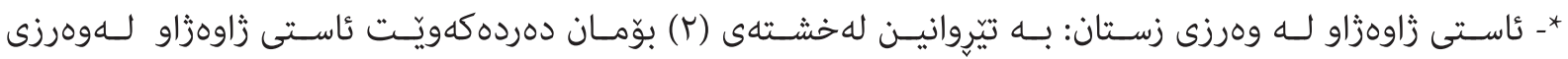

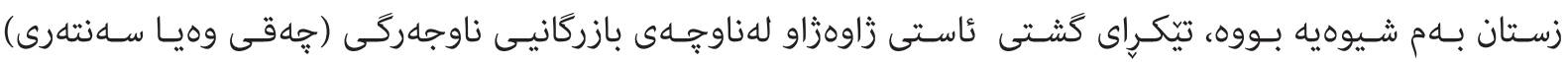

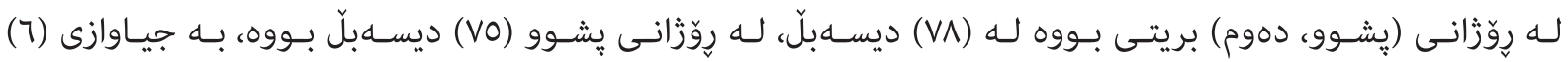

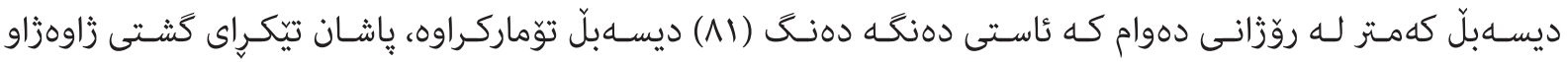

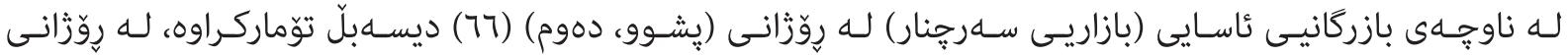

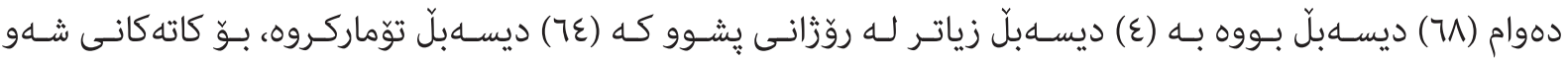

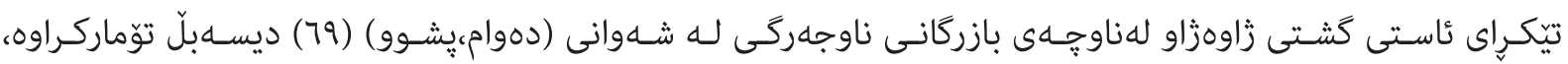

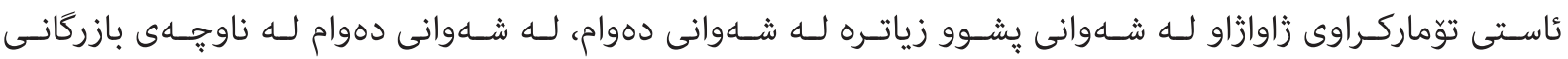

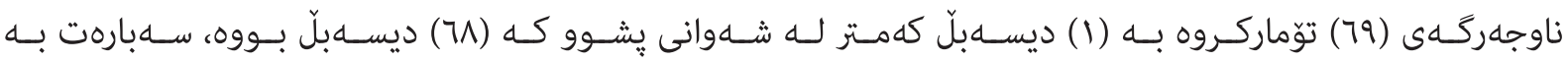

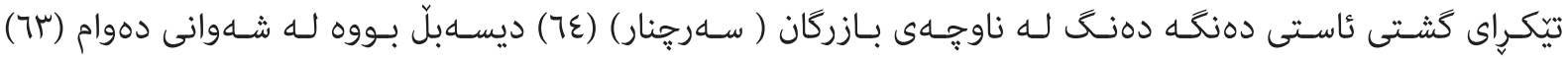
ديسـهبل بـووه بـه جيـاوازى (r) ديسـهبلّ زياتـر لـه شـهوانى دهوام كـه (70) ديسـهبلّ توّماركـراوه. 
شيّوهى (1) ئاستى يِيسبوون به زاوهزاو له ناوجهى بازركانيى لهوهرزى زستان

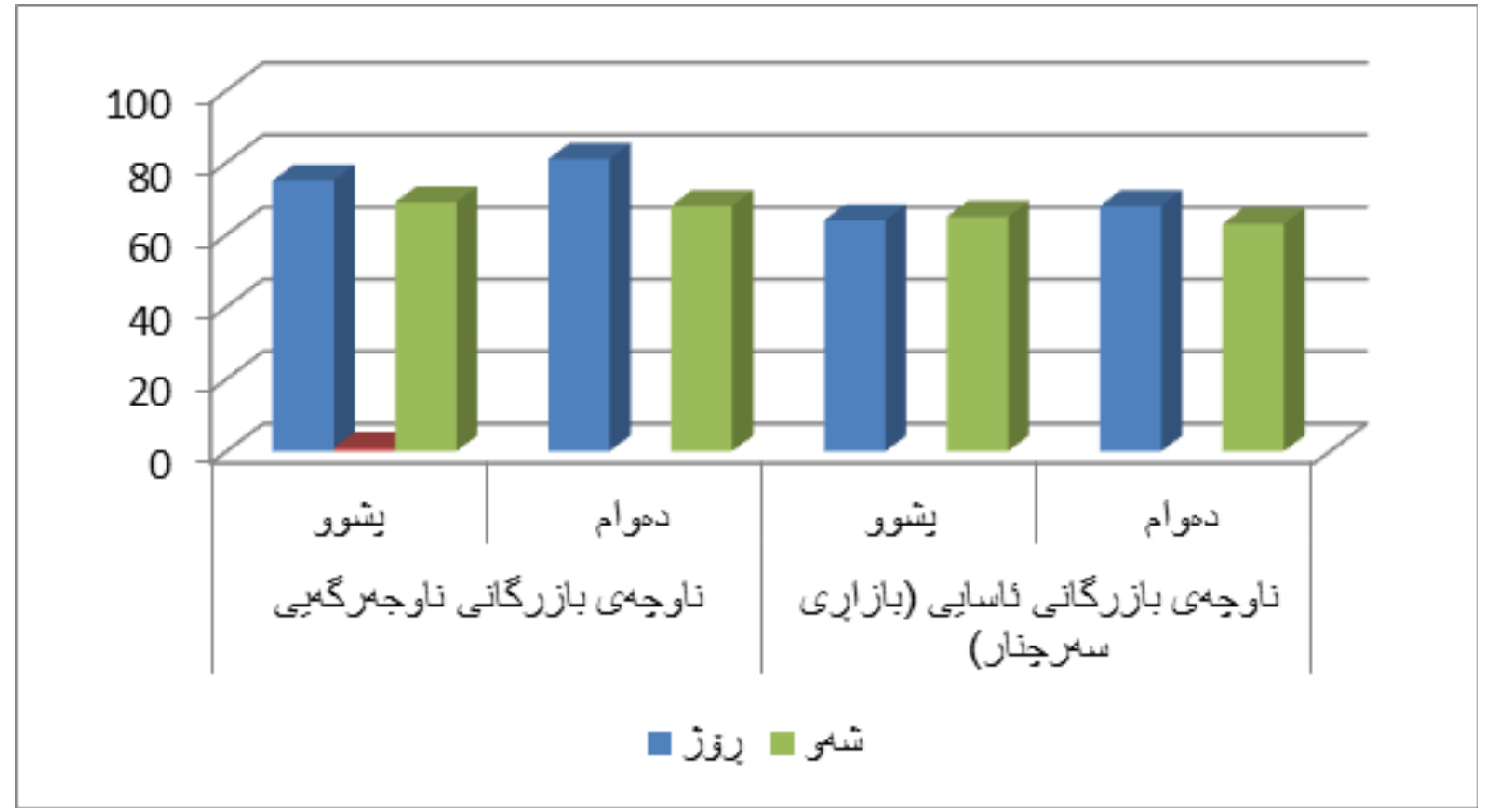

سهرجاوه: كارى تويَزَهران به يشت بهستن به خشتهى (r)

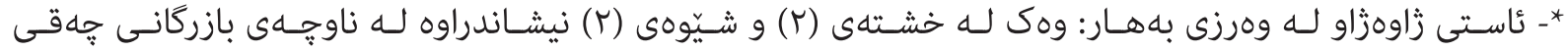

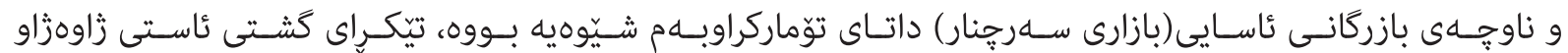

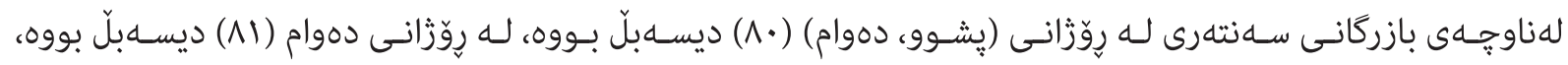

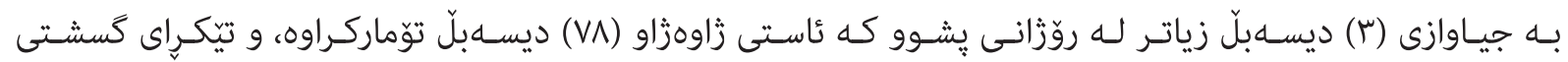

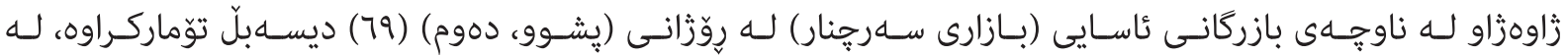

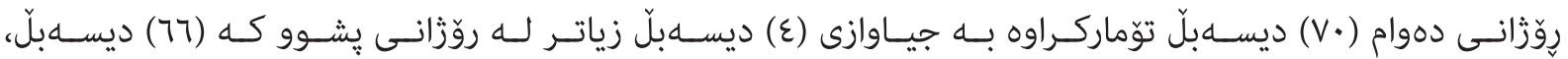

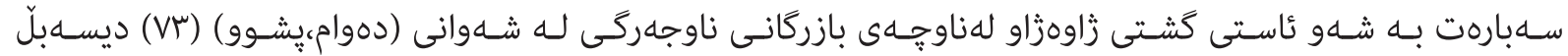

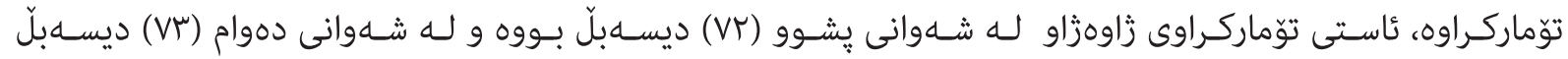

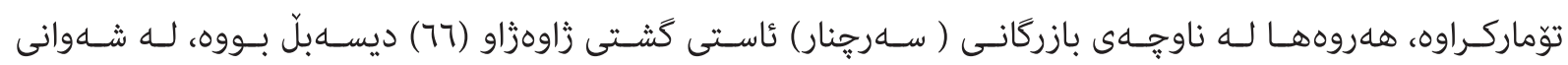

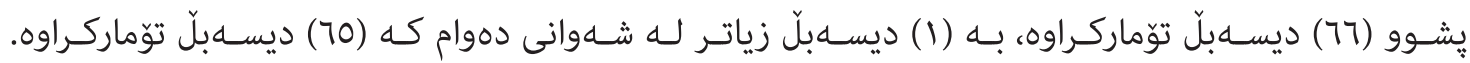


شيّوهى (Y) ناستى بِييسبوون به زاوهزاو له ناوجهى بازركانى لهوهرزى به هار

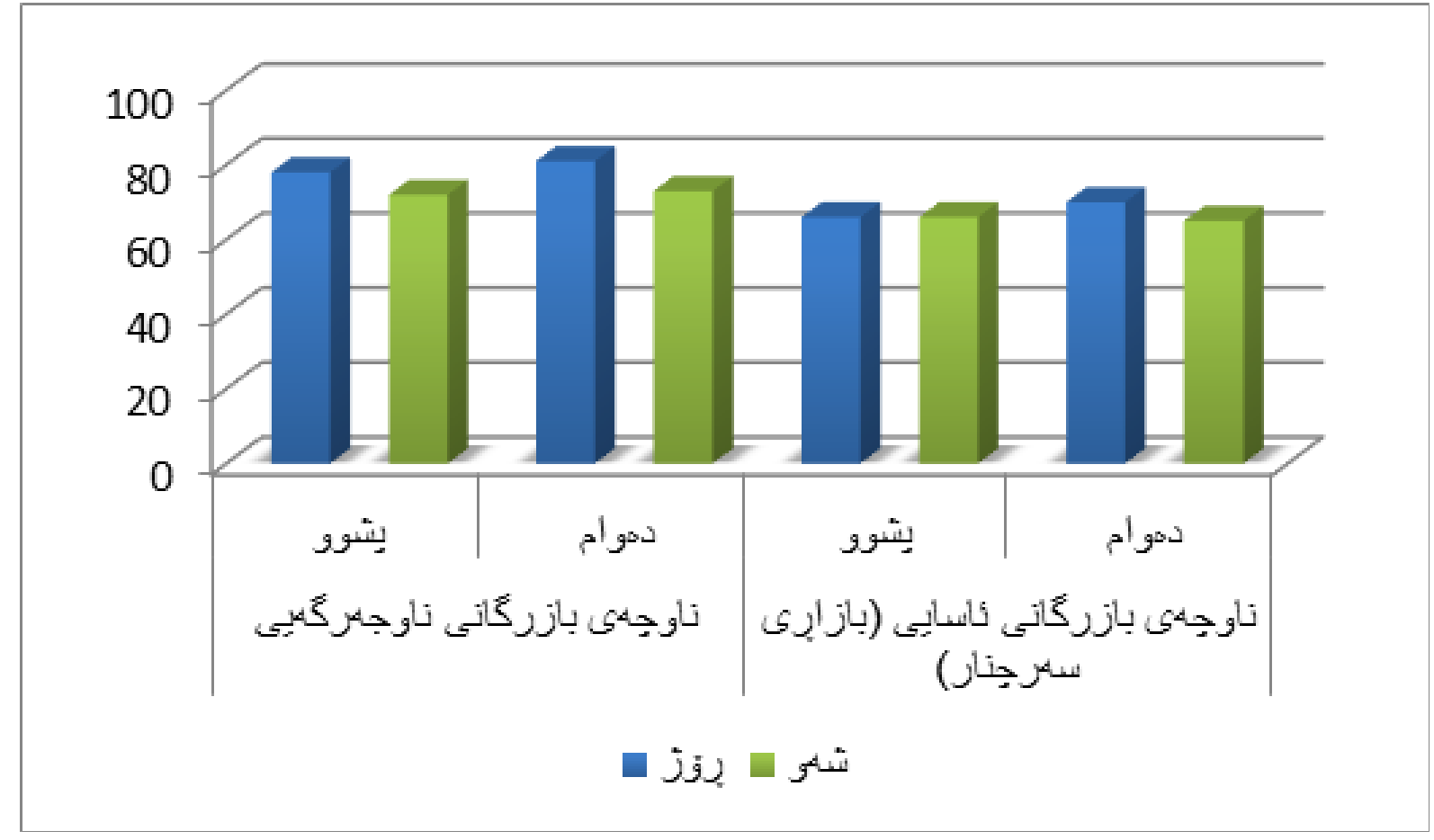

سهرجاوه: كارى تويَّزهران به يشت بهستن به خشتهى (r)

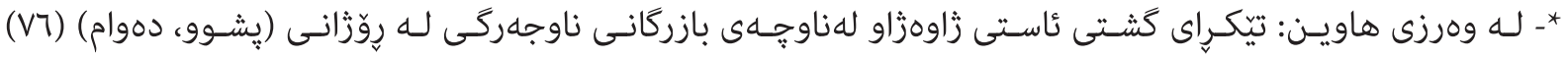

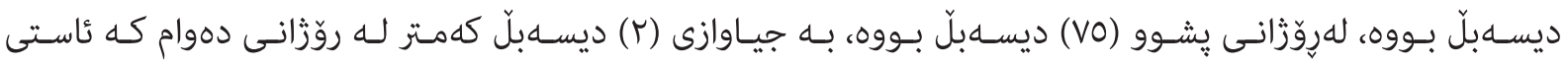

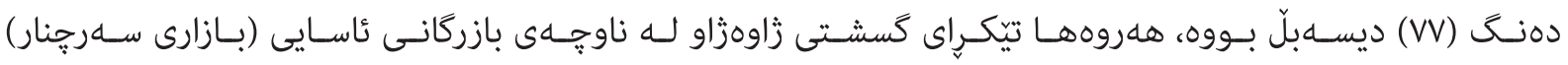

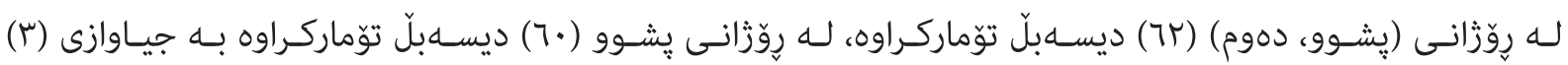

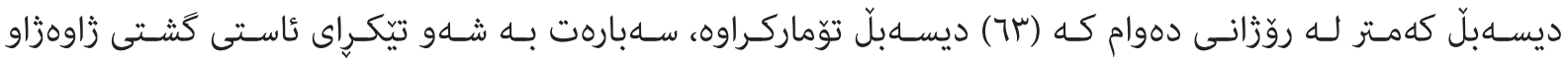

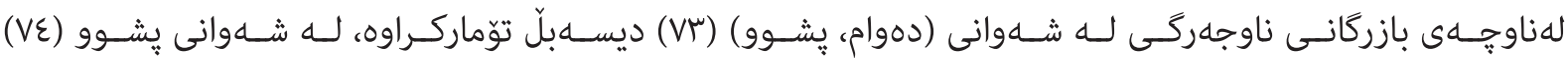

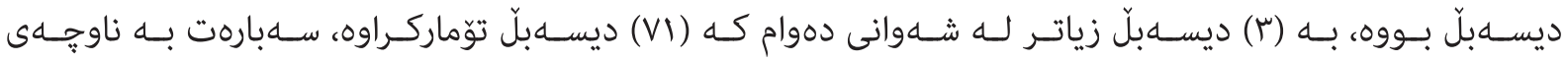

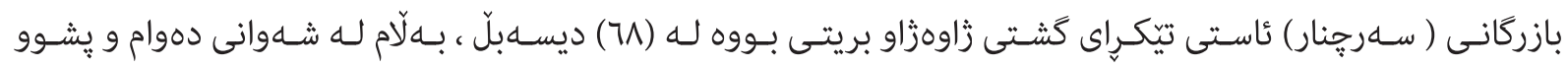

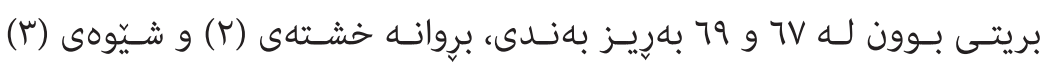


شَيْوهى (بّ) ئاستى يِيسبوون به زاوهزاو له ناوجهى بازركانى للوهرزى هاوين

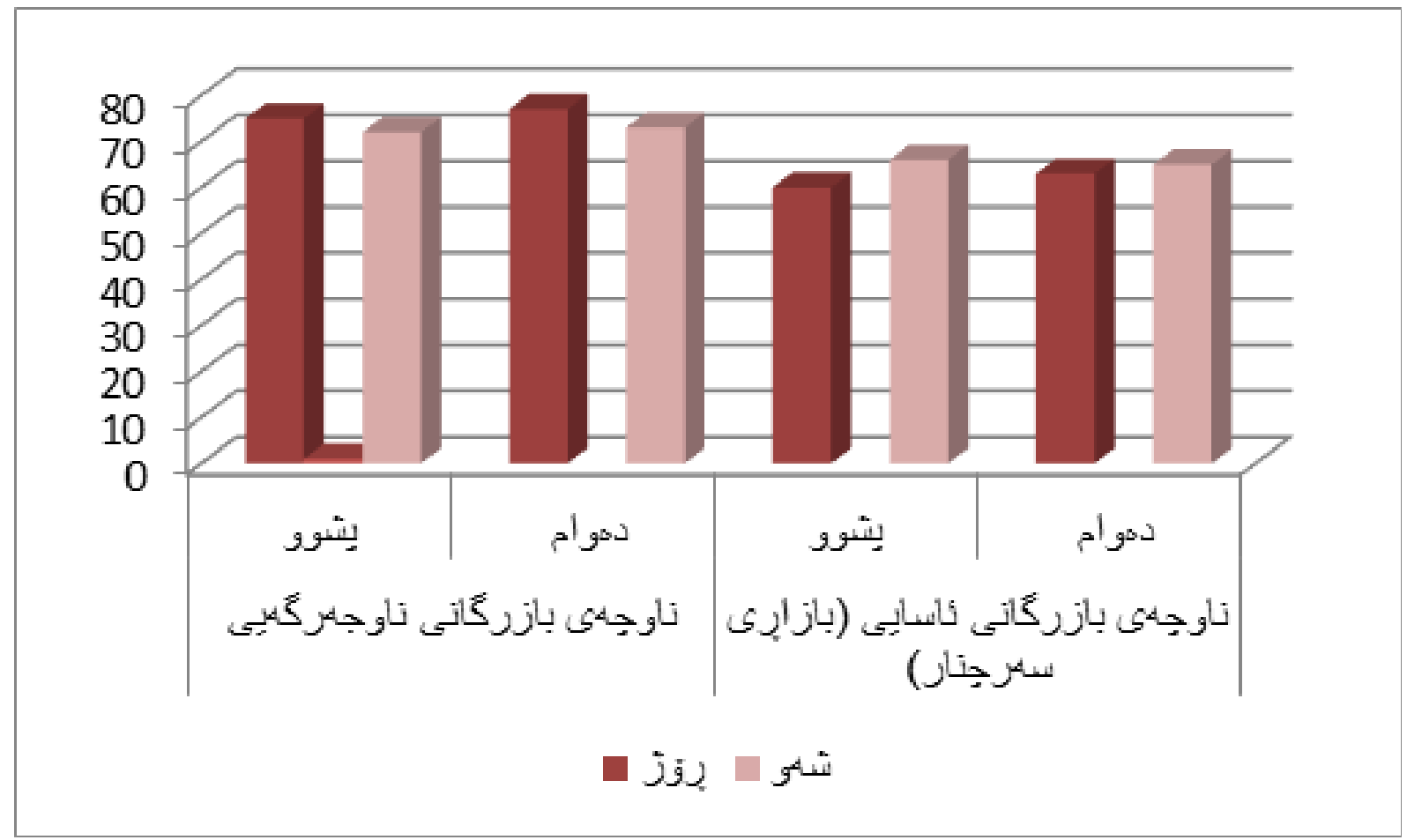

سهرجاوه: كارى تويَّزهران به يُشت بهستن به خشتهى (r)

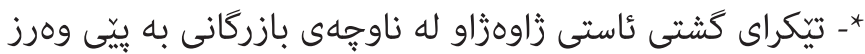

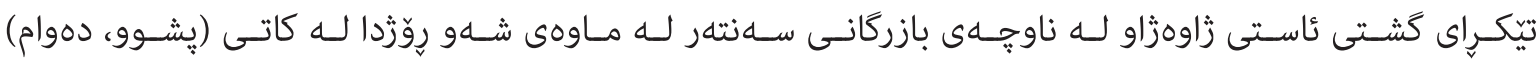

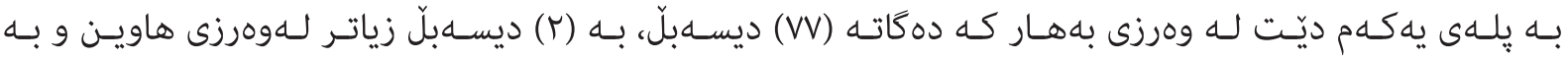

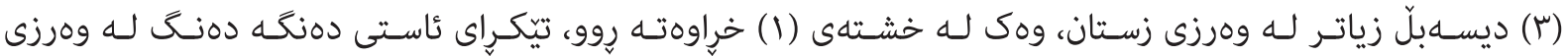

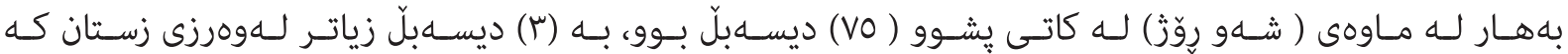

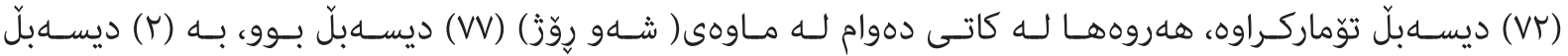

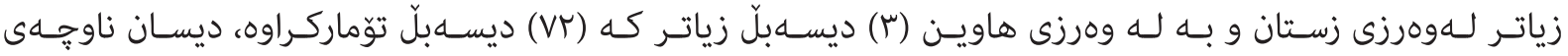

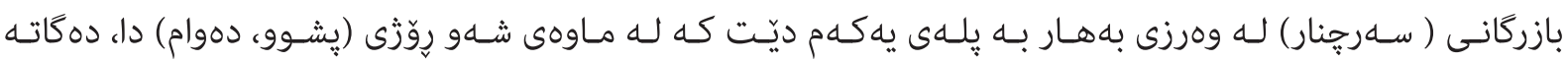

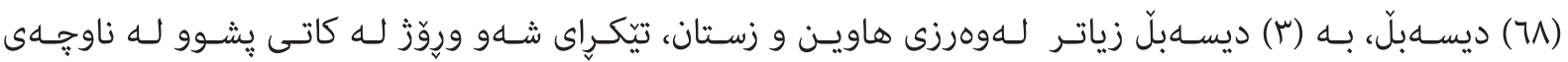

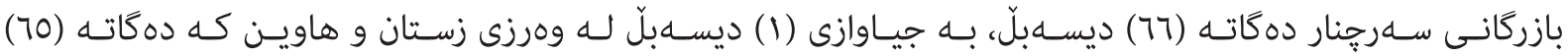

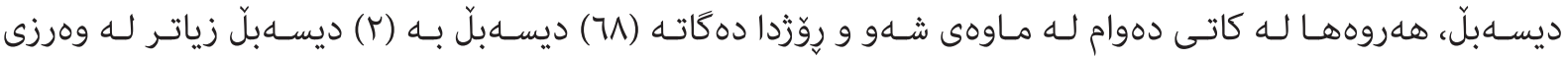

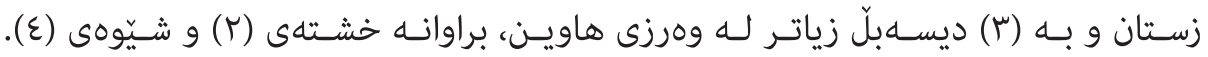




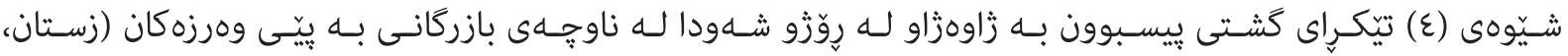
به بـار، هاويـن

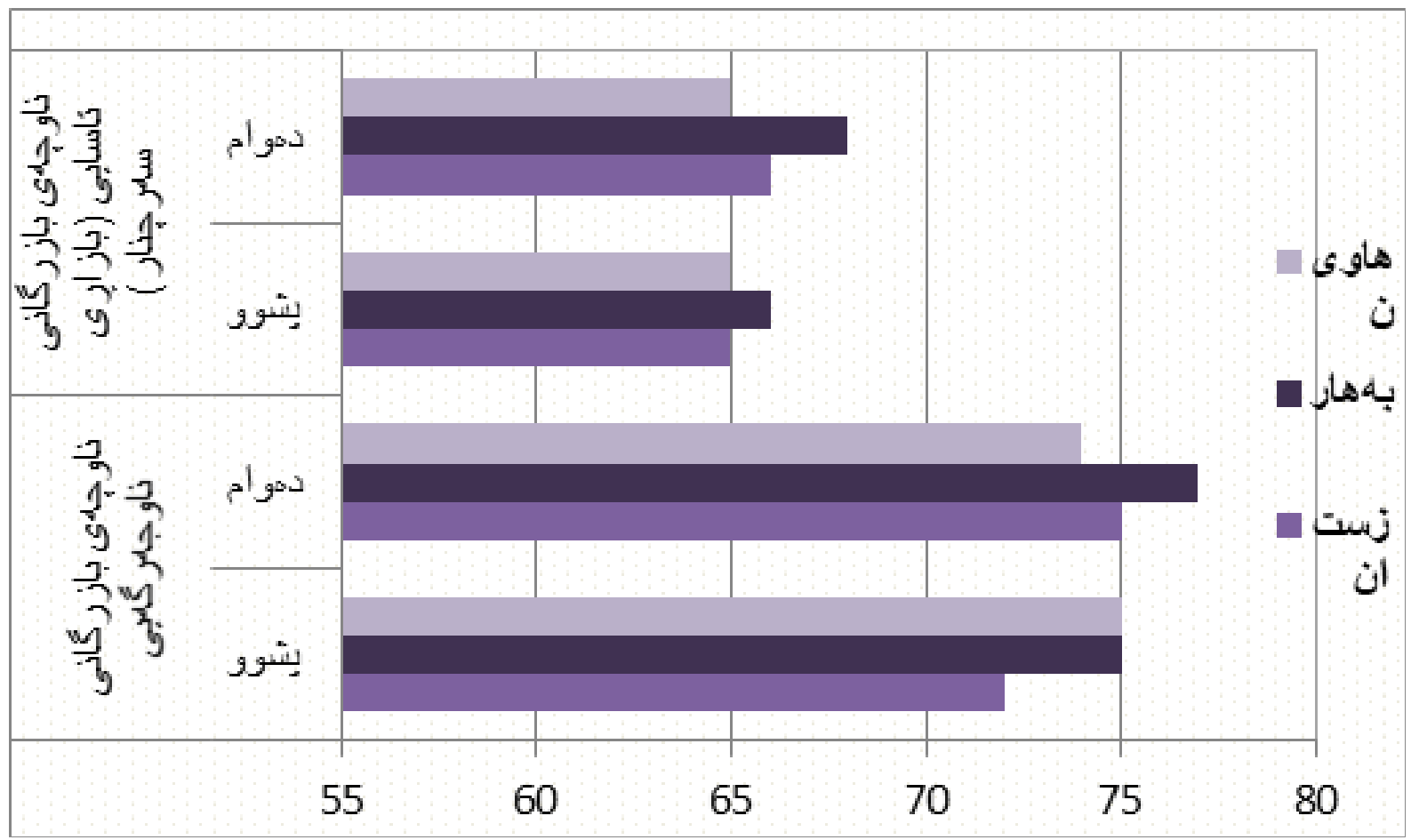

سهرجاوه: كارى تويَّرران به يُشت بهستن به خشتهى (r)

*- به شيكردنهوهى ئاستى زاوهزاو للهناوجه بازركانى دهكَينه ئهم خالآنهى لاى خوارهوه.

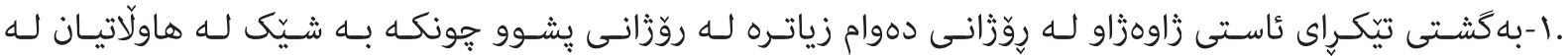

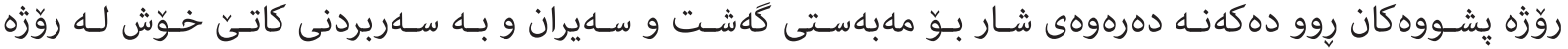

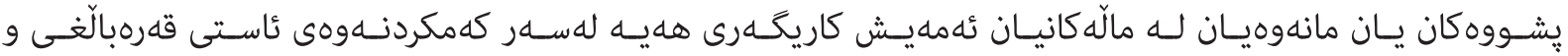

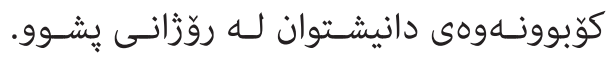

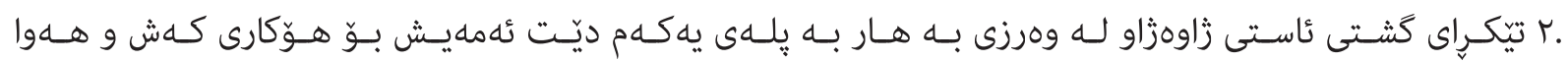

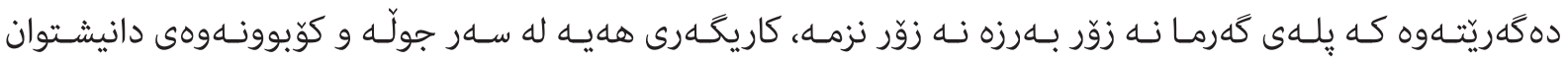

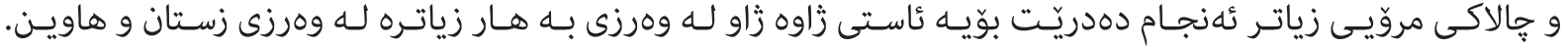

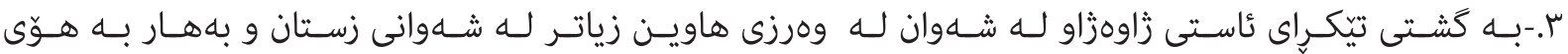

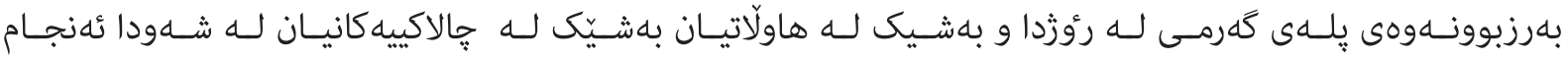




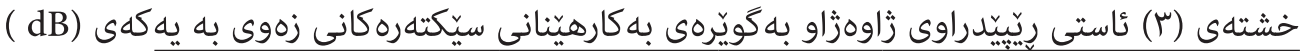

\begin{tabular}{|c|c|c|c|}
\hline كؤدى زوّن (ناوجهـ) & شـاهو & رِوَ & 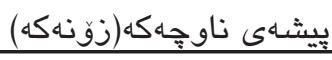 \\
\hline$A$ & 55 & 65 & هوّيـكاني بازركانيي \\
\hline$B$ & 45 & 55 & ناوجِهـ نيشته جيّبوون \\
\hline C & 70 & 75 & ناوجهاهى ِيشـاهسازى \\
\hline $\mathrm{D}$ & 40 & 50 & ناوجُهى هـهستيار \\
\hline
\end{tabular}

(Singh and davar $\mathrm{p} \backslash \Lambda, \mathrm{r} \cdot \cdot \varepsilon$, )

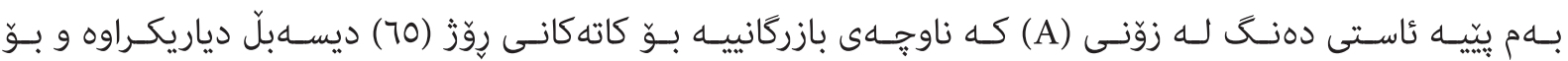
كاتهكانسى شـهو (00) ديسـهبل.

خشتهى (ع)

بهراوركردنى ئاستى زاوهزاو له ماوهى شهو و روّزَّا به كَيْرهى سيّكتهرهكانى بهكارهيّنانى زهوى له وهرزى ( زستان،

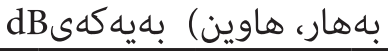

\begin{tabular}{|c|c|c|c|c|c|c|c|}
\hline \multicolumn{2}{|c|}{ وهرزى هاوين } & \multicolumn{2}{|c|}{ وهرزى بههار } & \multicolumn{3}{|c|}{ وهرزى زستان } & \multirow[t]{3}{*}{ شوينى وهركرتنى نموونهكان } \\
\hline 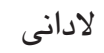 & 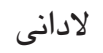 & 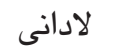 & 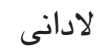 & 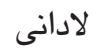 & 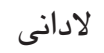 & \multirow[t]{2}{*}{ 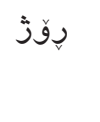 } & \\
\hline ليّيّوهر & 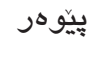 & 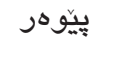 & ليّيّوهر & ينوّر & ي بيّيوهر & & \\
\hline dB19 & $\mathrm{dB} 10$ & dB17 & $\mathrm{dB} 13$ & $\mathrm{~dB} 14$ & $\mathrm{~dB} 10$ & يشوو & \multirow[t]{4}{*}{ ناوجهـى بازركانى ناوجهركهى } \\
\hline زياتر & زياتر & 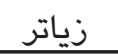 & زياتر & 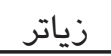 & زياتر & & \\
\hline dB16 & $\mathrm{dB} 12$ & dB18 & dB16 & dB13 & dB16 & دهوام & \\
\hline زياتر & زياتر & زياتر & زياتر & & زياتر & & \\
\hline $\mathrm{dB} 14$ & dB5 & & dB1 & $\mathrm{dB} 10$ & $\mathrm{~dB} 1$ & يشوو & \multirow{4}{*}{ 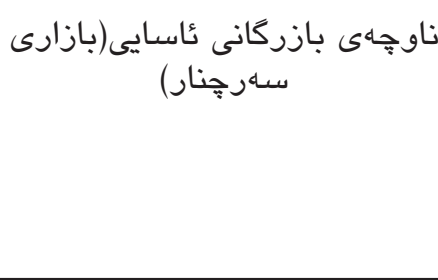 } \\
\hline زياتر & كهمتر & زياتر & زياتر & 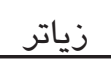 & 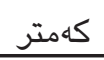 & & \\
\hline $\mathrm{dB} 12$ & $\mathrm{~dB} 2$ & dB10 & dB5 & $\mathrm{dB} 13$ & dB3 & \multirow[t]{2}{*}{ 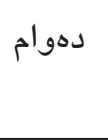 } & \\
\hline زياتر & كهمتر & زياتر & زياتر & زياتر & زياتر & & \\
\hline $\mathrm{dB} 18$ & dB11 & dB18 & dB15 & $\mathrm{dB} 14$ & $\mathrm{~dB} 13$ & \multirow{2}{*}{ دهووام } & \multirow{2}{*}{ 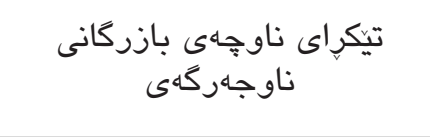 } \\
\hline 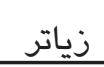 & زياتر & زياتر & زياتر & زياتر & زياتر & & \\
\hline $\mathrm{dB} 13$ & dB3 & $\mathrm{dB} 11$ & dB4 & dB9 & $\mathrm{dB} 1$ & \multirow{2}{*}{ "دهوام - } & \multirow{2}{*}{ 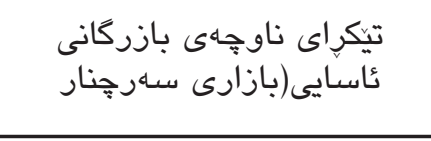 } \\
\hline زياتر & كهمتر & زياتر & زياتر & زياتر & زياتر & & \\
\hline
\end{tabular}

سهرجٍاوه: كارى تويَّزهران به يُشت بهستن به خشتهى (r)

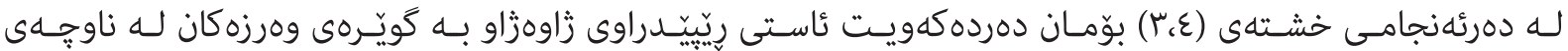
تويَزينـهوه كـه بـهم شَيْوهيه بــور

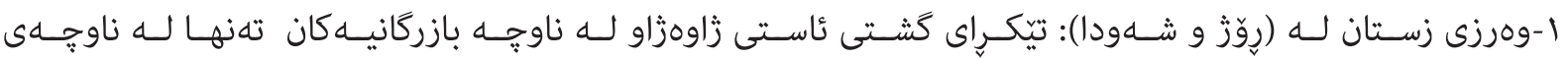




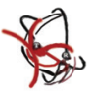

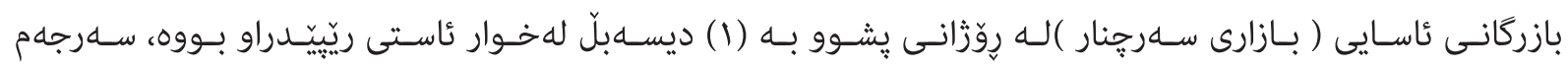

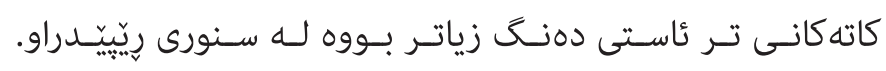

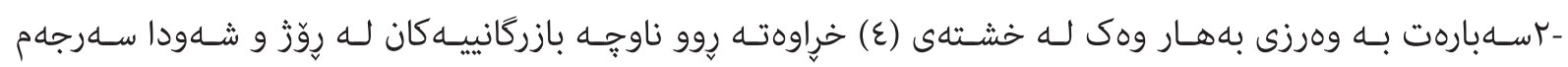

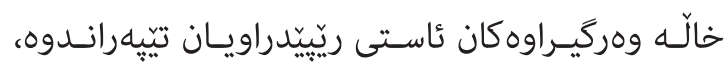

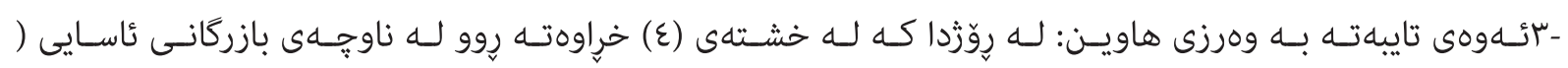

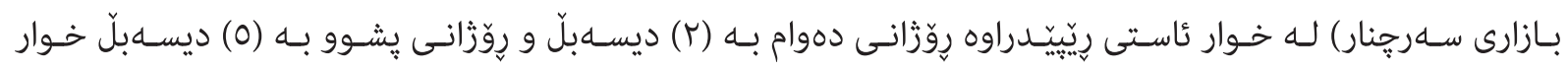

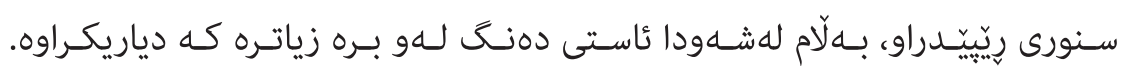

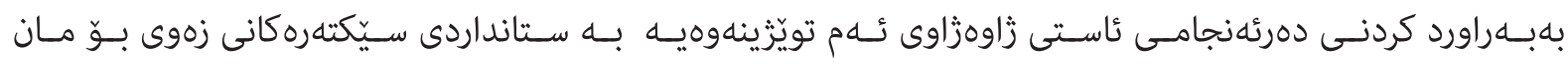

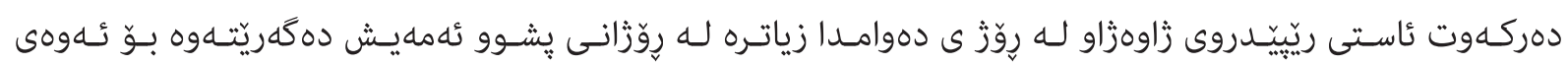

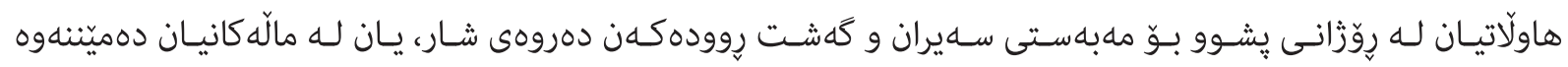

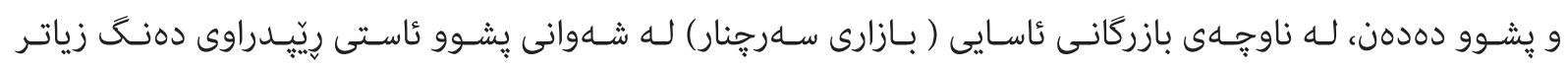

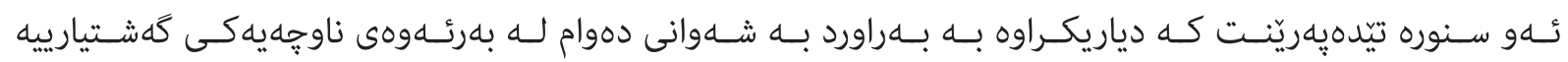

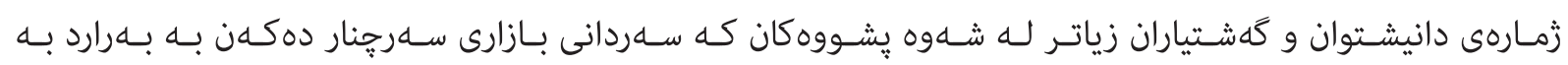

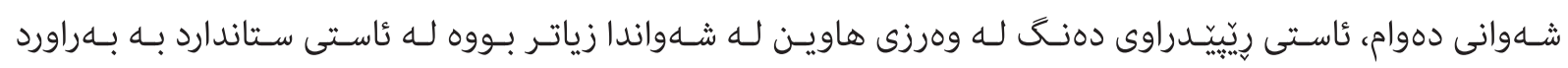

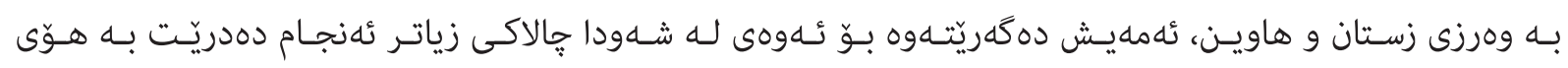

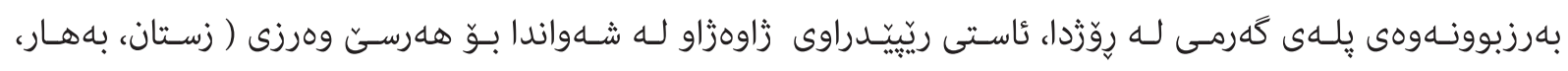

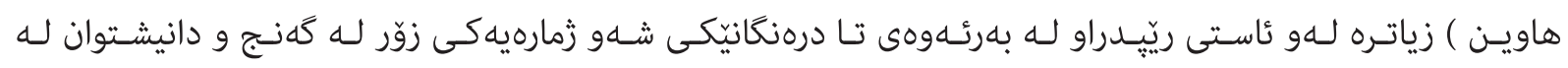

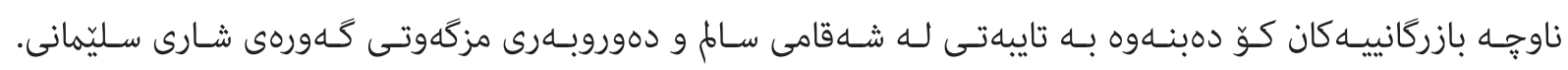

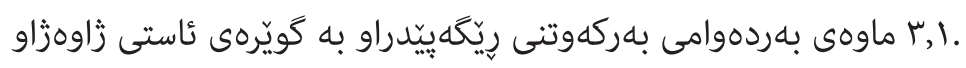

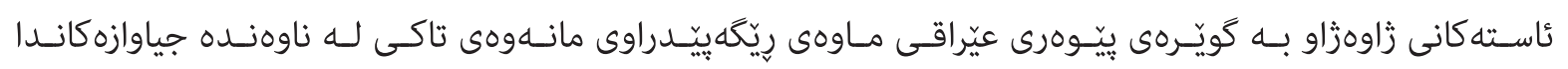

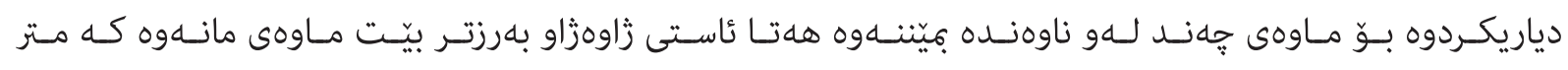

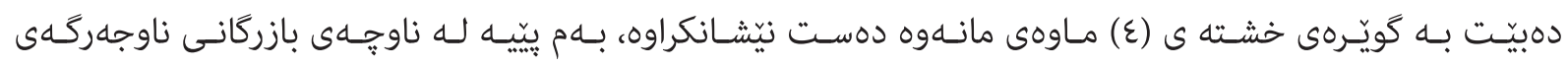

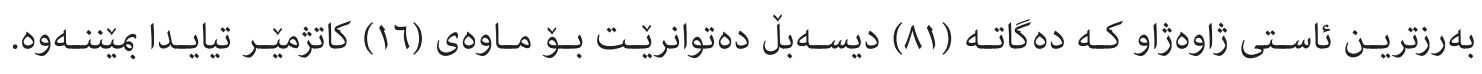


خشتهى (0 ) (0) ئاستى به هيّزى زاوهزاو و ماوهى بهركهوتنى بهdB / كاتزميّر

\begin{tabular}{|c|c|}
\hline 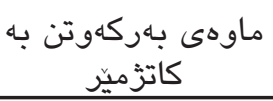 & عاستى دهنگ بـdB \\
\hline 17 & $\Lambda$. \\
\hline$\wedge$ & 10 \\
\hline$\varepsilon$ & 9. \\
\hline$r$ & 90 \\
\hline 1 & $1 \ldots$ \\
\hline$r / I$ & 1.0 \\
\hline$\varepsilon / 1$ & 11. \\
\hline$N / 1$ & 110 \\
\hline
\end{tabular}

سهرجاوه: الوقائع العراقية، 10 •

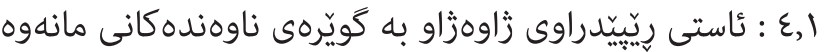

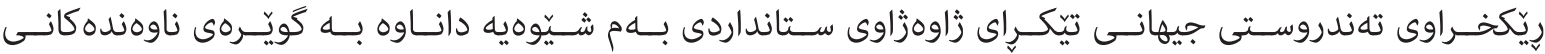

$$
\text { مانــوهى مـروّق }
$$

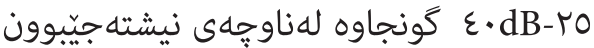

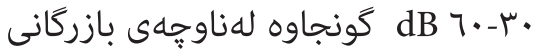
كونجاوهله ناوجهى يِيشهسازيدا

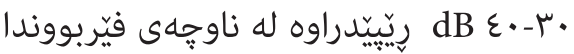

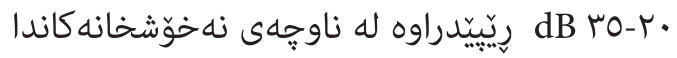
dB T.

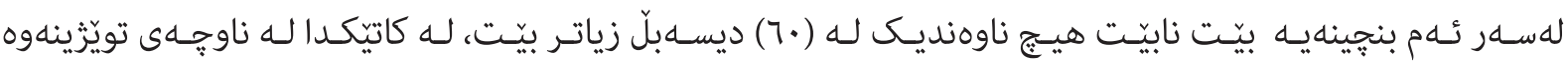

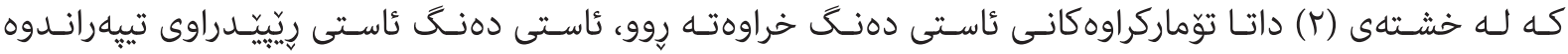

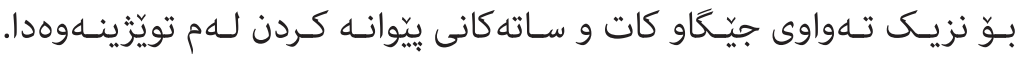

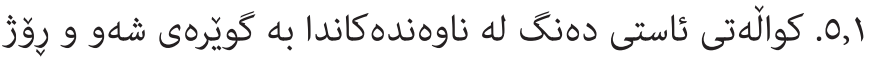

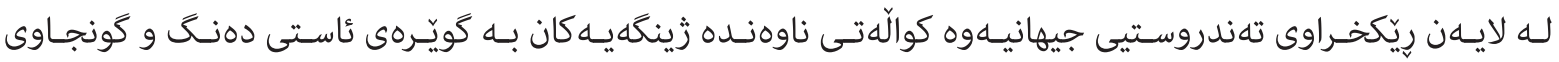

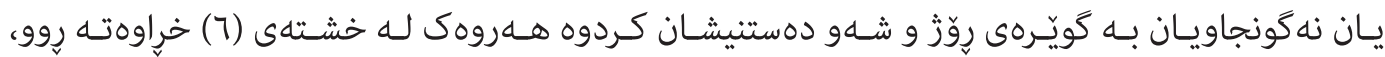




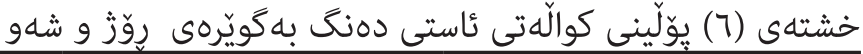

\begin{tabular}{|c|c|c|c|}
\hline \multicolumn{2}{|c|}{ كاتى شـاهو } & \multicolumn{2}{|c|}{ كاتى روّذ } \\
\hline كوالّتى دهنگ & ئاستى دهنك به dB & كوالّتي ددنگ & ئاستى دهنك به dB \\
\hline ناياب & $30-0$ & ناياب & $r \cdot-$. \\
\hline زوّرباش & $40-31$ & زوّرباش & $\varepsilon \cdot-r)$ \\
\hline باشـ & $50-41$ & باشـه & $7 \cdot-\varepsilon 1$ \\
\hline טֶه سـاند & $65-51$ & يֶهسهند & Vo-71 \\
\hline ن نهشياو & $75-66$ & نهاهياو & $9 \cdot-\sqrt{7}$ \\
\hline مـترسيدار & $90-76$ & مهترسيدار & $11 \cdot-91$ \\
\hline 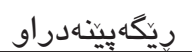 & زياتر 90 & ريَّكَه يِيناهدراو & 111 زياتر \\
\hline
\end{tabular}

$. \varepsilon V \mu p, r \cdot 1 \mu$, Anomohanran And Ochujo

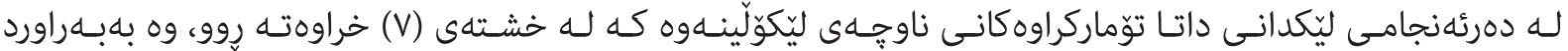

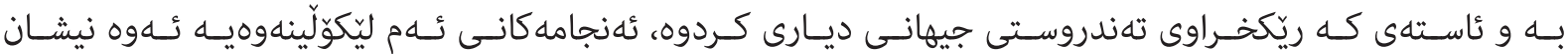

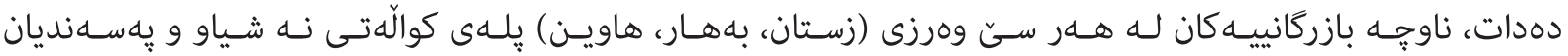

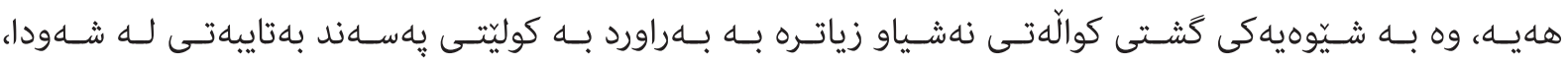

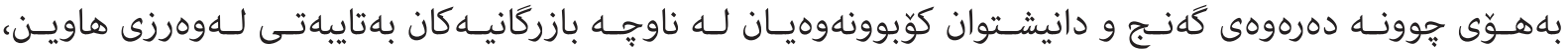

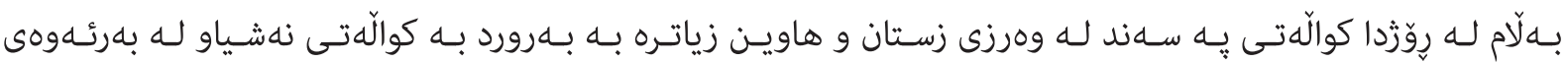

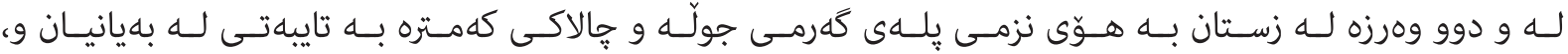

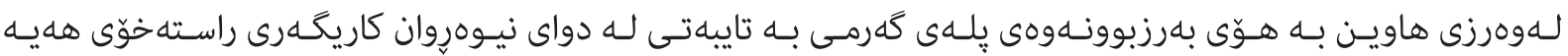

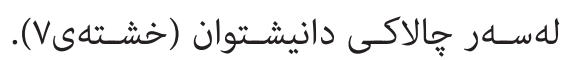




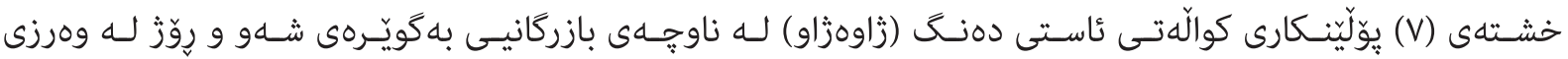

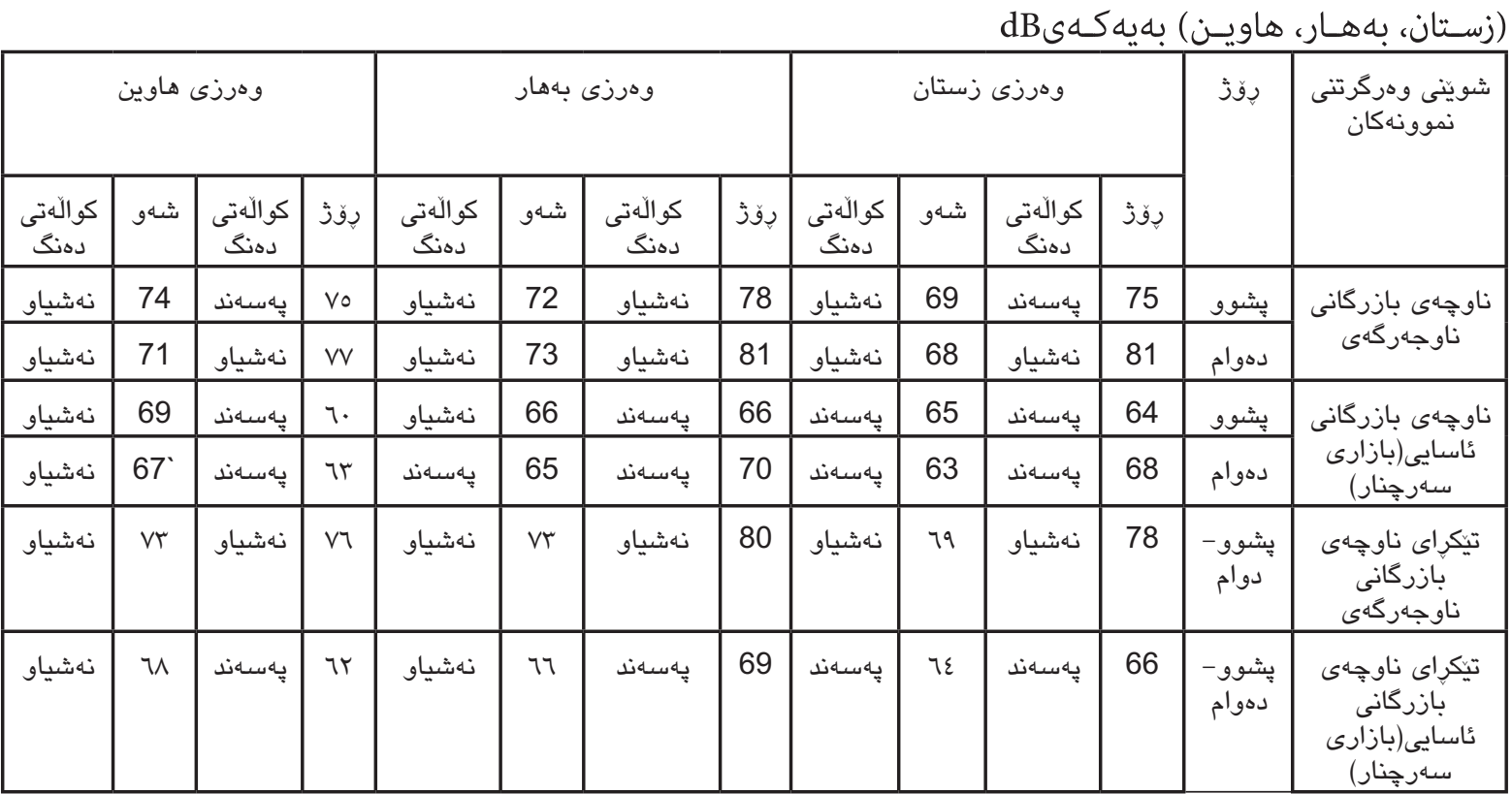

سهرجٍاوه: كارى تويَزْهران به يشت بهستن به خشتهى (r)

باسى سيّيه: دمرهاويّشته كانى زاوهزاو و جِونيهتى جارهسهركردنى زاوهزاو

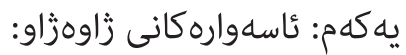

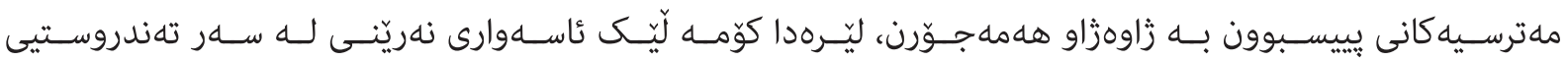

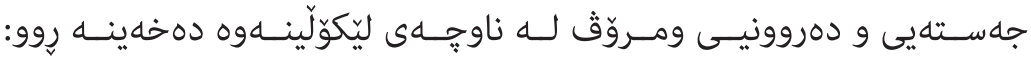
ا - كاريكهريى زاوهزاو لهسهر كوّئهندامى بيستن

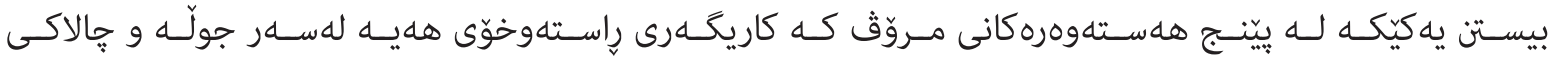

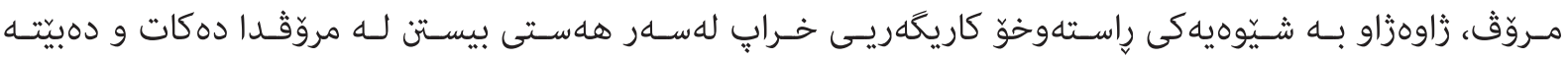

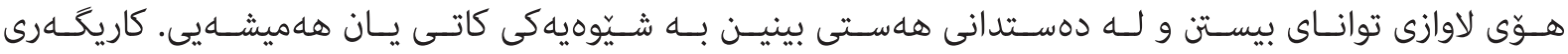

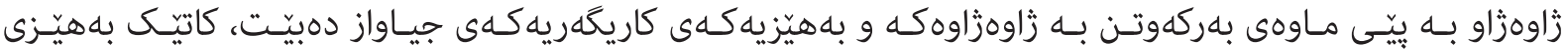

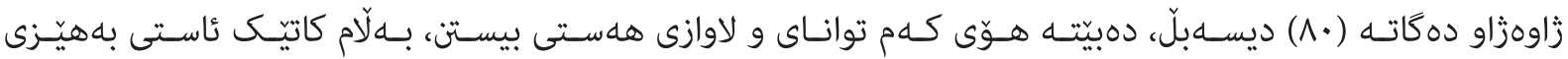

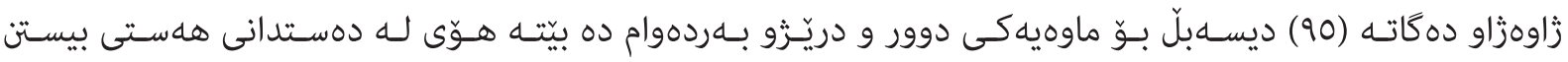

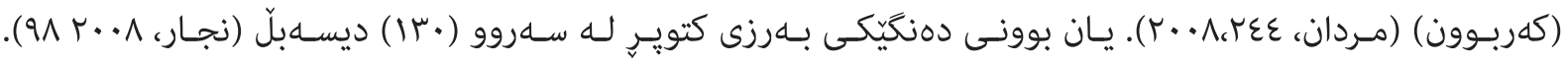

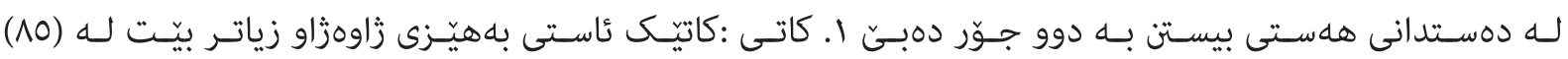

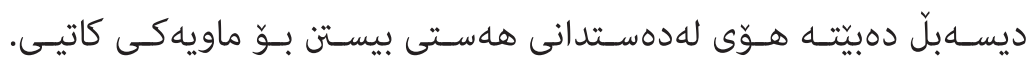

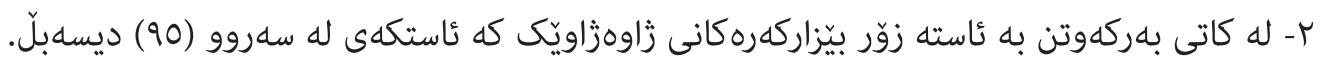

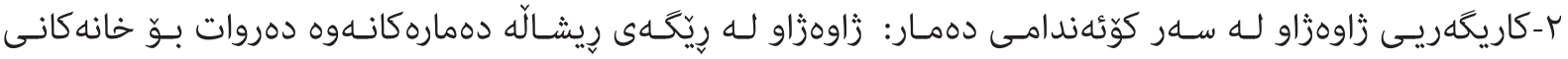

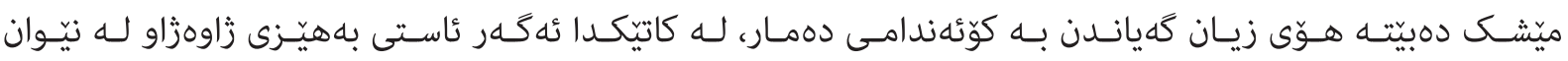

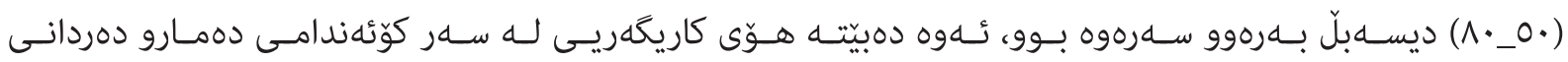




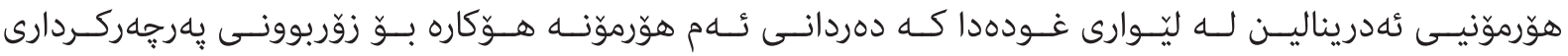

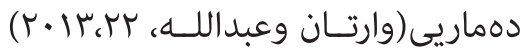

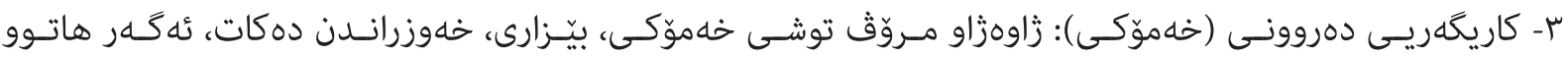

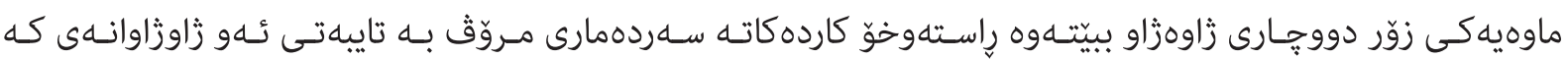

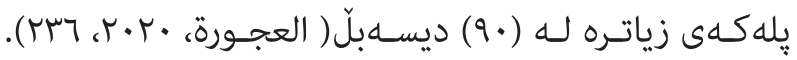

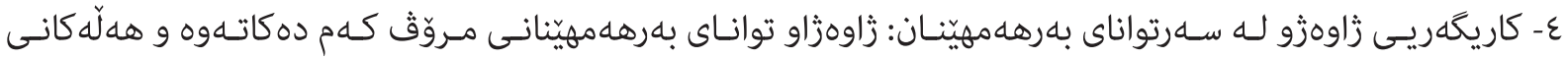

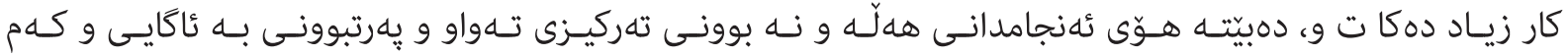

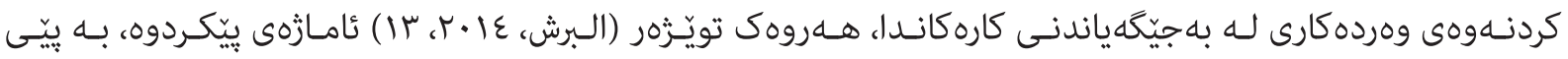

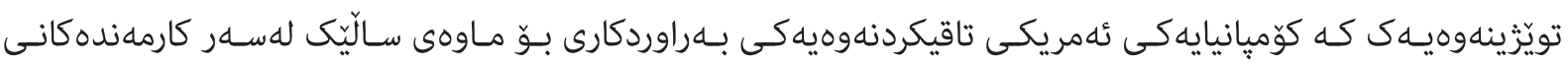

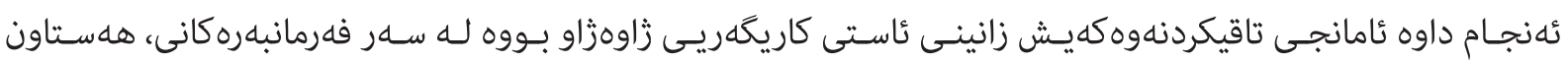

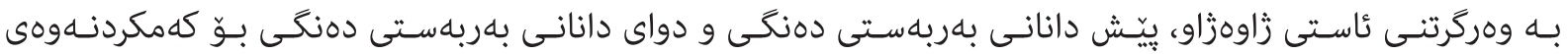
ئاسـتى زاوهزو ئهنجامـه كان بـهم شَيْوهيه بـوون:

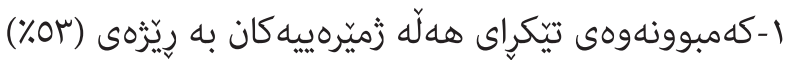

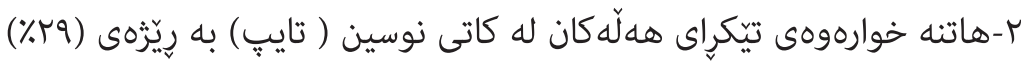

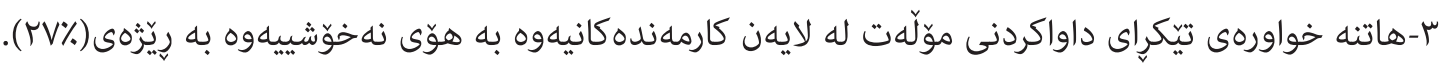

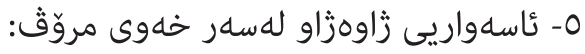

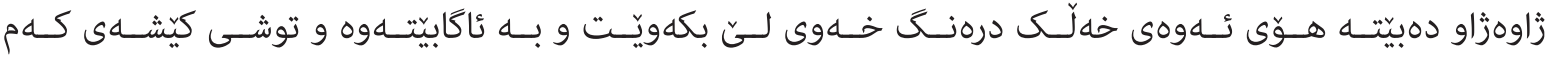

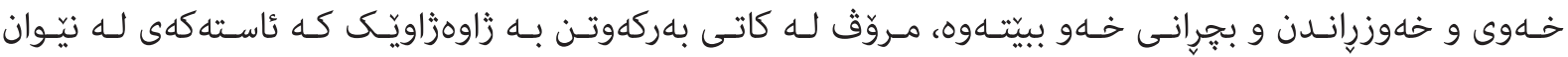

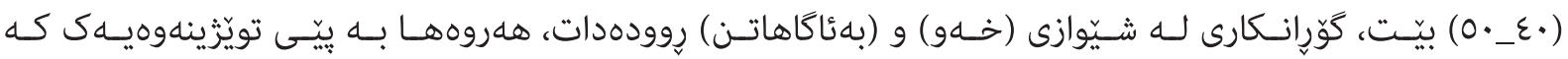

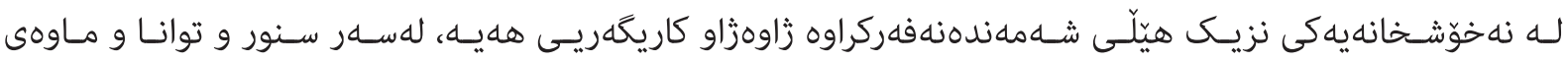

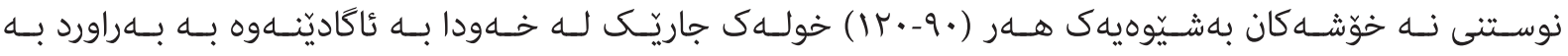

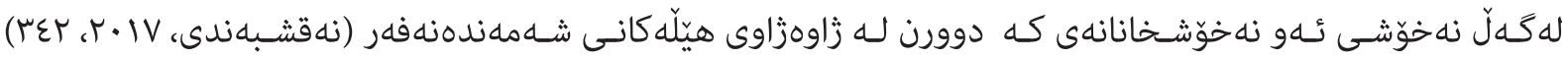

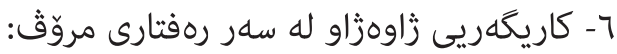

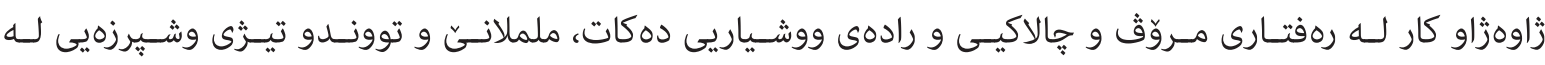

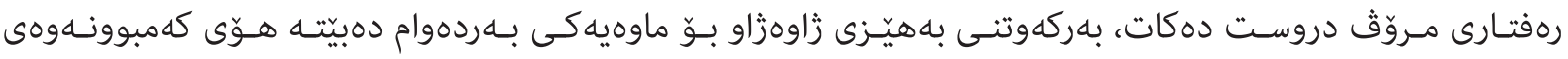

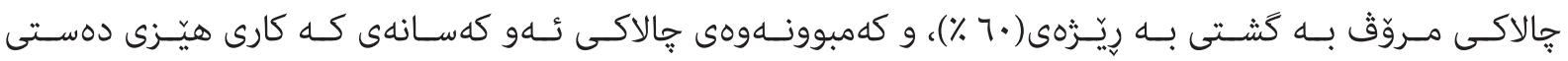

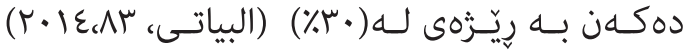

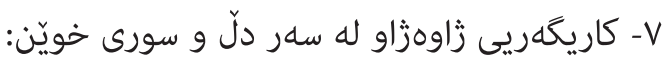

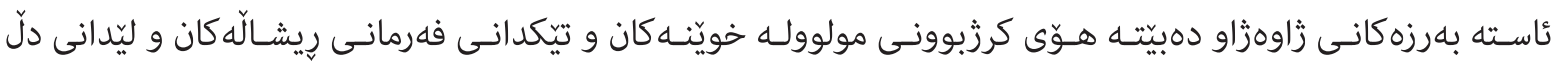

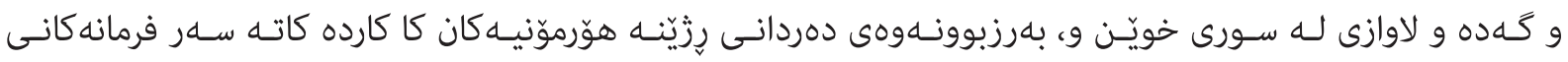

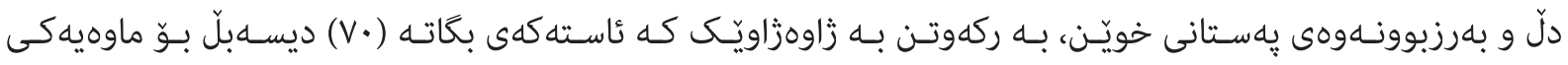

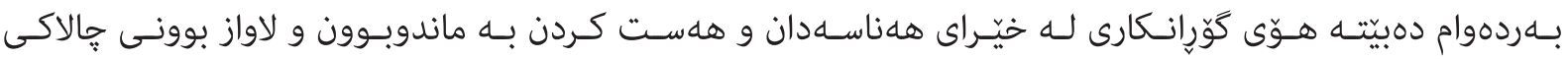




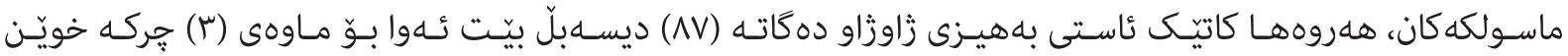

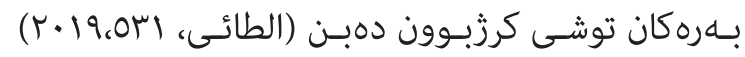

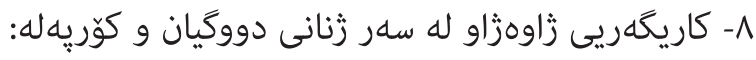

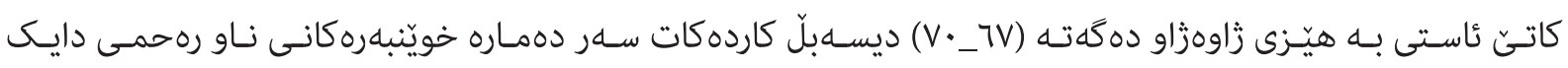

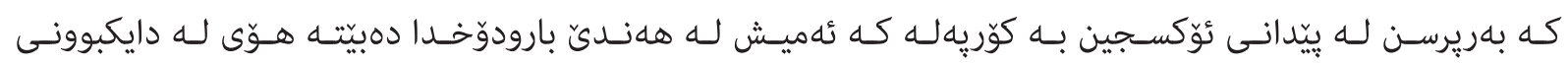

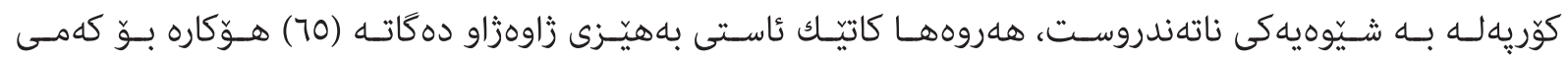
كيّشـى منــالَ (19VA,US EPA)

9- كاريكهريى زاوهزاو له سهر يهروهرد0دى ( خويّندكاران)

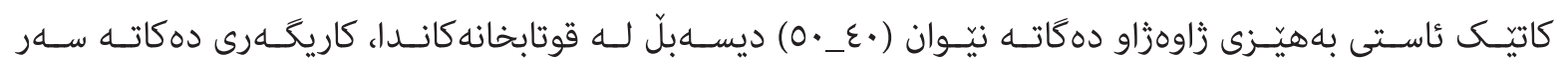

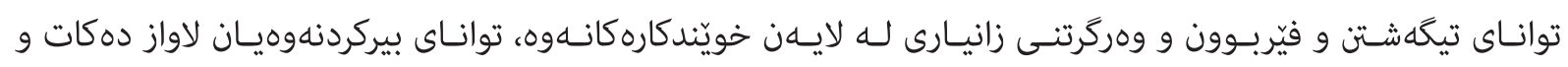

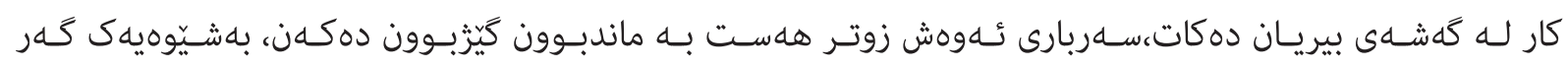

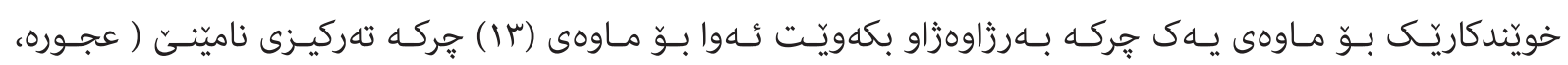
$\left(r \cdot 1 \varepsilon_{c}\right) q V$

به شيَوهيه كَى كَتى ناسته كانى زاوهزاو به كَويّرهى يه ستانى دهنكَه كه ئهم ئاسهوارانهى هليه:-

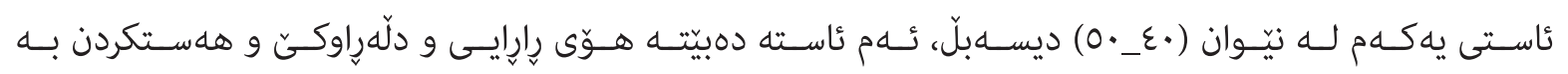
ماندويّتـى درووونيـى.

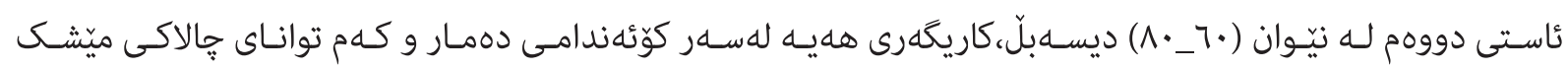

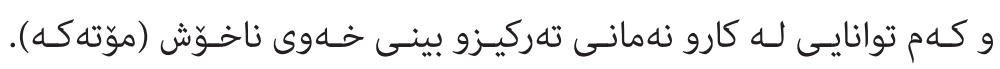

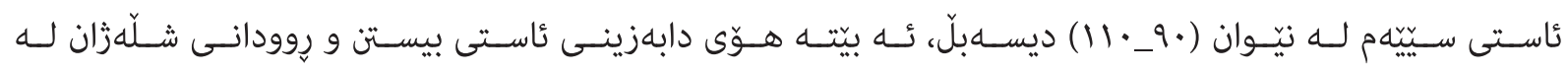
كوّئهندامسى دهمـارو دلّ.

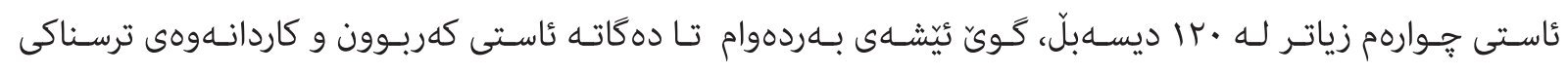

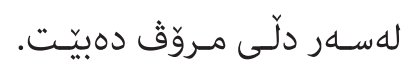

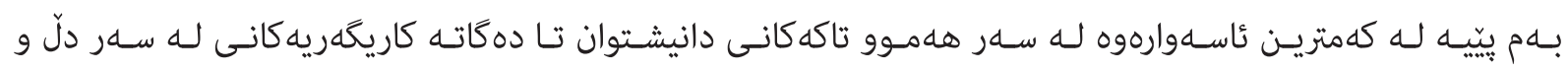

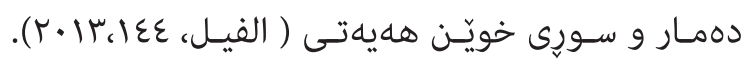

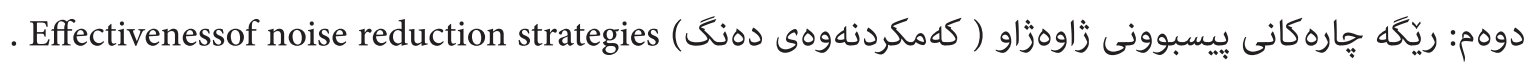

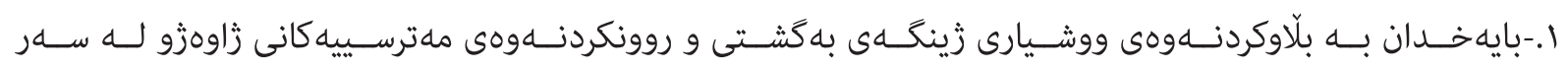

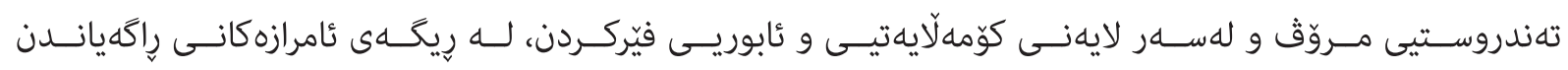

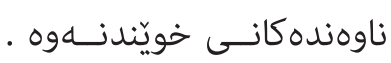

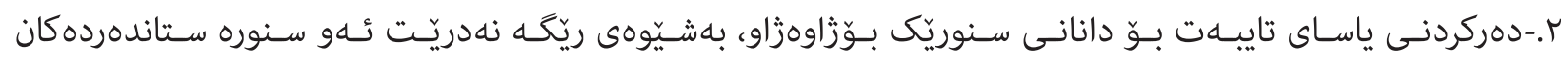

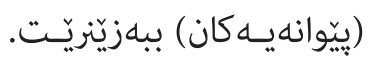

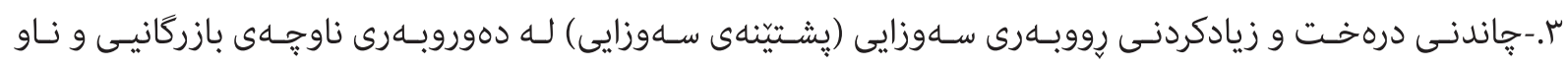

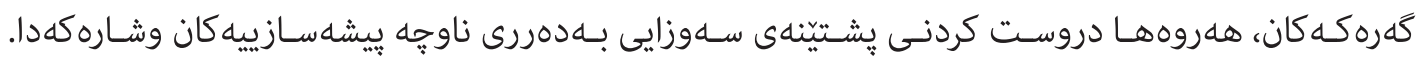

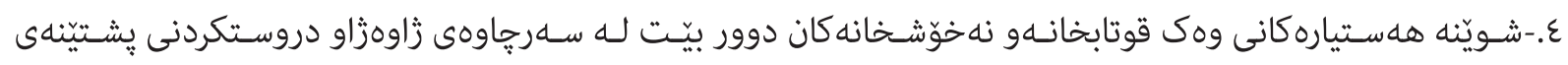


سـهوزى بــه دموريانـدا.

ه. خوّياراستن له زاوهزاو له رِيَكَى كهم مانهوه يان دوور كهوتنهوه له و شويَنانهى زاوهزاوى تيّدا بهرزه.

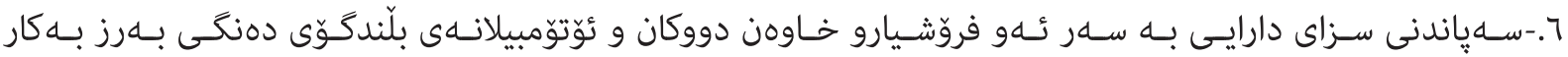

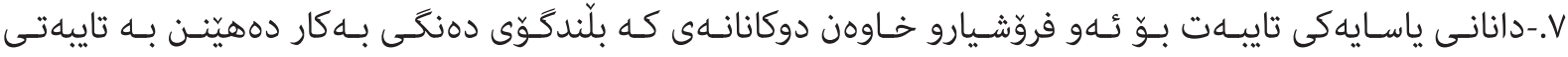
كهوروكه كان.

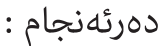

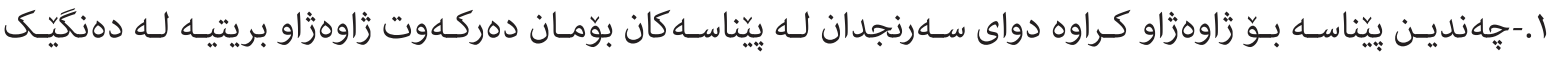

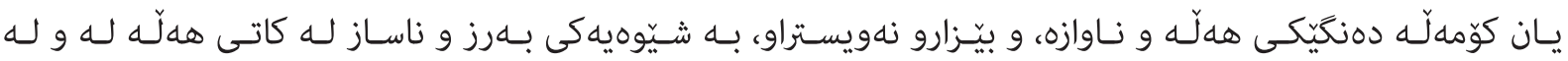

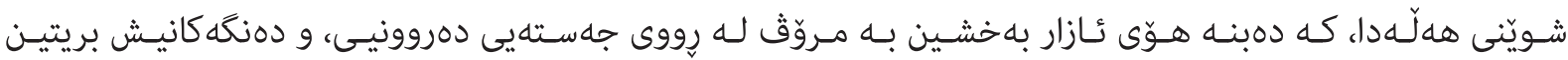

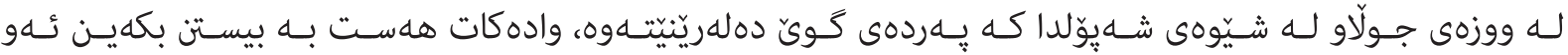

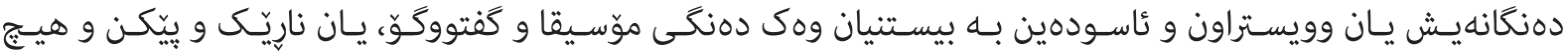
ئاوازيـك لـه دهنكه كـه نيـه وه بيسـتنيان بيّزاركهره.

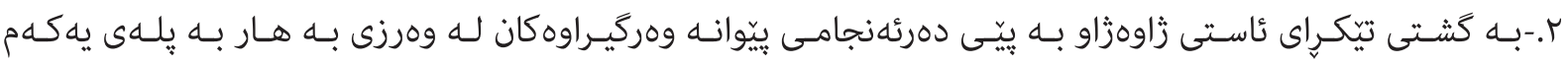

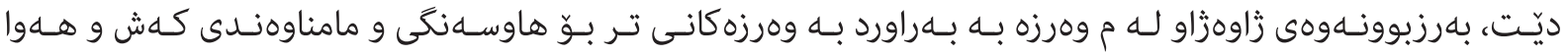

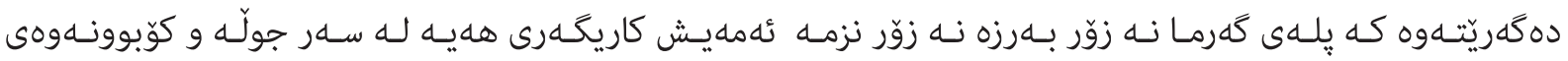

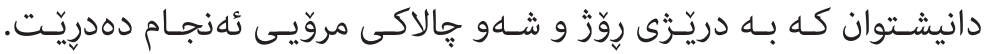

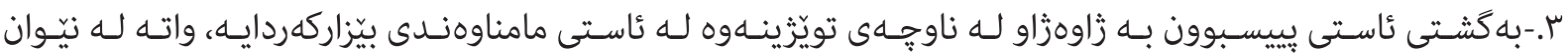

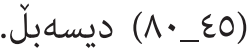

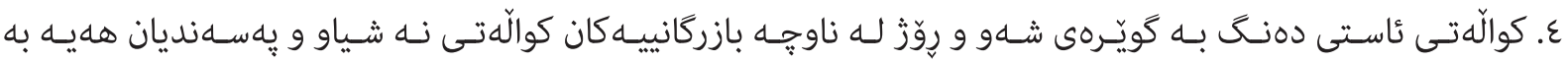

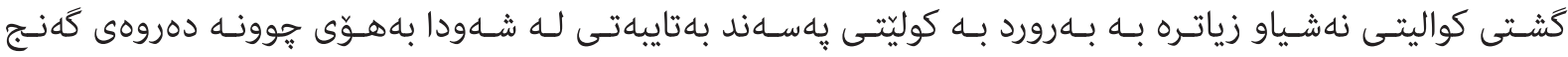
ودانيشـتوان كوّبوونهوهيـان لـه ناوجـهـ بازركانييـهـ كان بهتايبهتى لـهوهرزى هاوينــا .

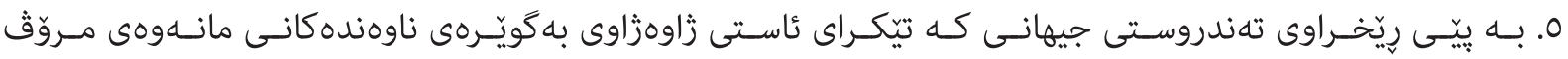

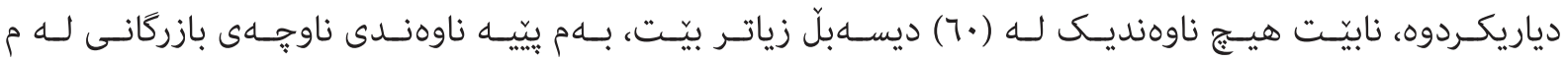

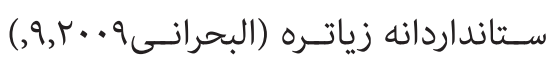

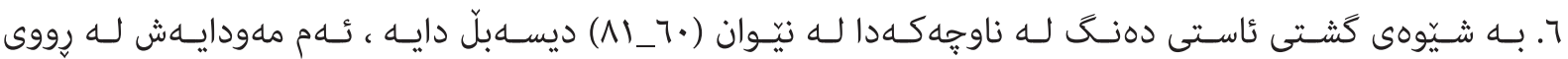

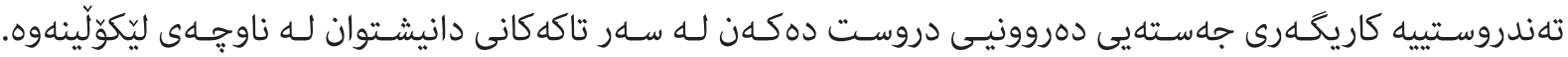

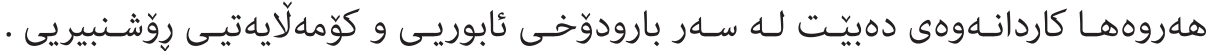

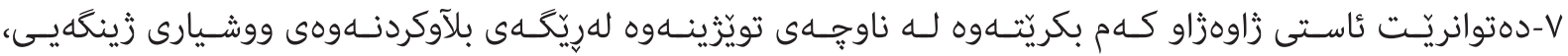

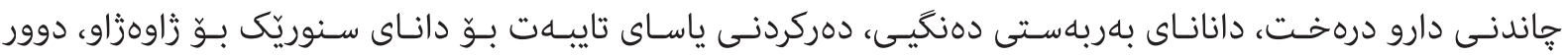
كهوتنـهوه لـه و شـوينانهى زاوهزاو تيّــا بـهرزه. 


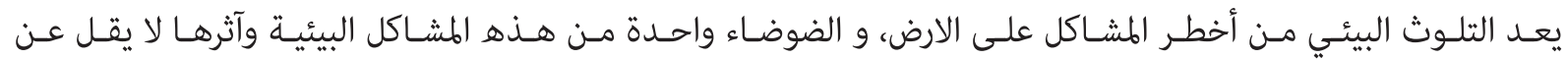

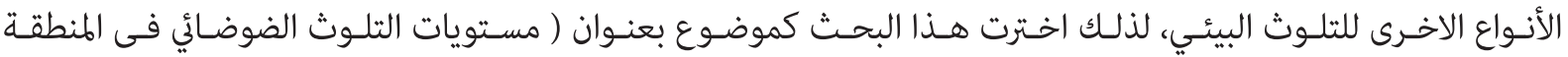

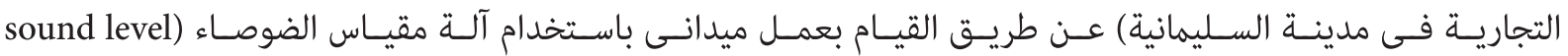

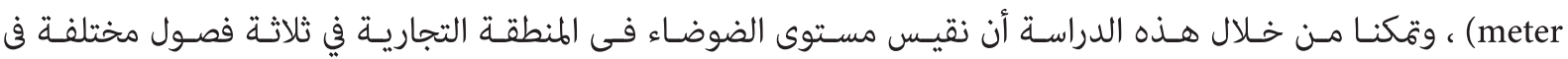

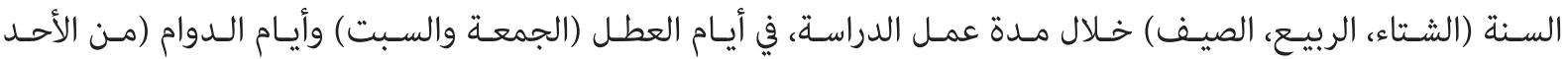
إلى الخميـس)، وخـلال الليـل والنهـار، الهـدف، هـو إظهـار آثـار الضوضــاء عـلى الصحـة البدنيـة و السـيكولوجية للإنسـان،

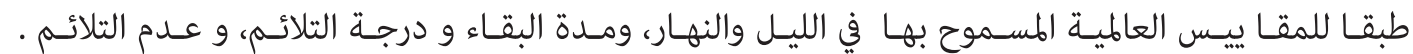
و كشـفت هـــه الدراسـة أن مدينـة السـليمانية تجـاوزت المسـتوى الطبيعى للضوضـاء في المنطقـة التجاريـة، و وفقـا لنتائج

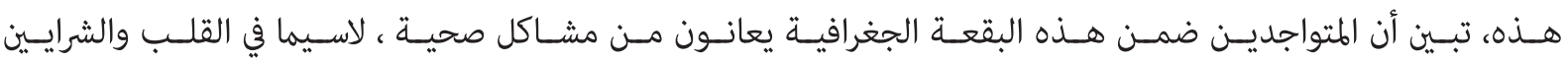
والـدورة الدمويـة، مقارنـة بالمناطـق الســنية الاخـرى.

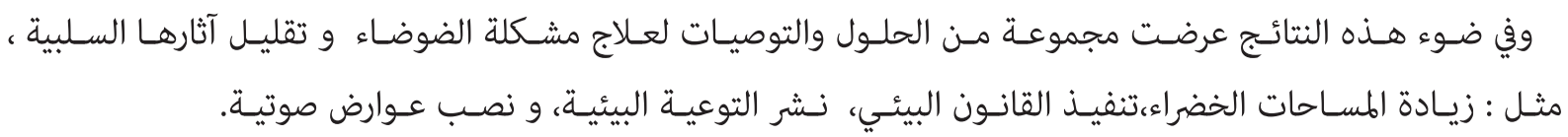

\section{The Levels of Environmental Pollution by Noise in the Industrial Areas of Sulaimani City in Kurdistan Region of Iraq}

\section{Abstract}

Environmental pollution is one of the biggest problems that face humanity and it is very dangerous matter these days. Furthermore, excessive noise is regarded as a significant environmental pollution like other environmental pollutions. Therefore, the aim of this research was to assess noise pollution levels and its effects on the environment at the commercial and Industrial zone in Sulemani city The noise levels were measured by using a sound level meter. This research of noise assessment was conducted in three different seasons which were summer, spring, and winter. Noise pollution was measured on official working days from Sunday to Thursday and in the day and night periods. Moreover, noise levels were measured on weekend days, Friday and Saturday, and in both daytime and nighttime periods as well. Also, the aim of this research was to identify and investigate noise effects on human being body and psychological characteristics. In view of the obtained results, we also concluded that the background noise level in the study area has exceeded the permissible international noise standards, and this causing posing a serious threat to people's health and having negative consequences for their heart, veins, and blood circulation system. Therefore, this study strongly suggests that it is necessary to develop a noise abatement strategy and programme of strategic noise reduction in the study area, such as building barriers between the noise sources and peoples; locating noisy equipment as far as possible from hospitals, schools, work areas; implementation of environmentalist policies and regulations; etc.

Keywords: noise pollution, Suleymani industrial, noise measurement, effects and solution. 


\section{سله קاوهكان}

يهكهم: كتيّب

ا. الفيـل على عدنـان، شرح التــوث البئـي فـى قوانيـن حمايـة البيئـة العربيـة، الطبعـة الآولى المركز القومسى للآصدارات

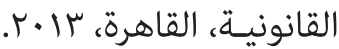

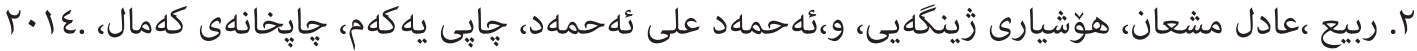

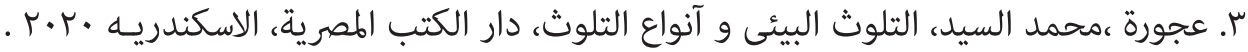
ع. مقيلى، محمد عياد، التلوث البيئى، الطبعة الآولى، دار شموع الثقافة، ليبيا. r.. r.

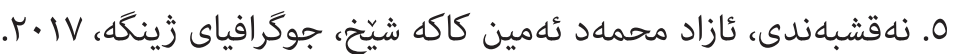
.$\ulcorner\cdot \wedge$,Wang K. Lawrence K. Wang, et all, Advanced Air and Noise Pollution Control .^

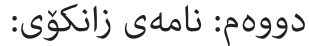
ا. الكلابـى، انـور صبـاح محمــ تلـوث الهـواء والهيـاه والضوضـاء داخـل المسـكن و خارجـة فى مدينـة السـماوة، آطروحـة دكتـوراه ( غيـر منشـور) جامعة البـصرة- ككيـة لآداب، ساء •r.

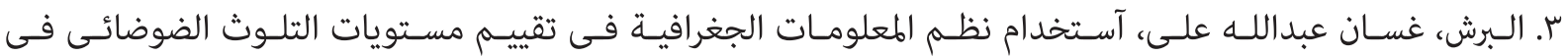

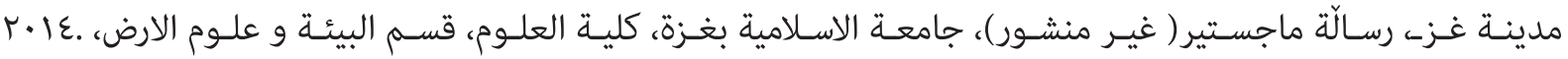

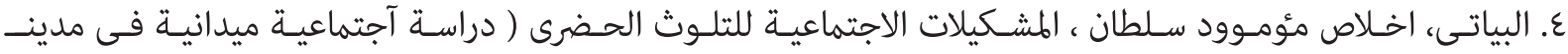
الديوانيـة) رسـالة ماجسـتير ، كليـة الاداب جامعـة القادسـية ،عا •r.

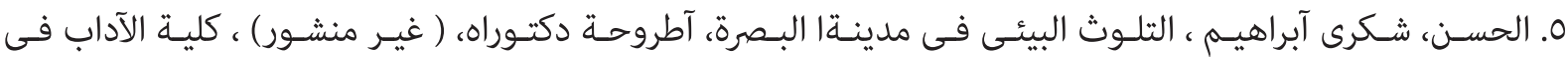

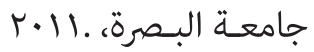

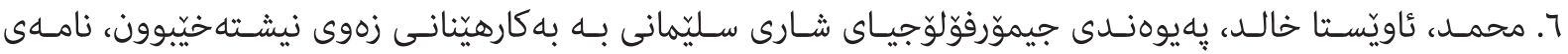

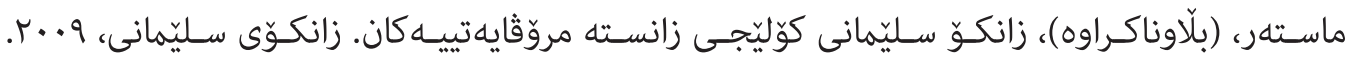
V. نجـار، فتحيـة فليـح عبــ الكريـم، الآمـراض ولخدمـات الصحيـة فى مناطق مختـارة مـن محافظـة رام الله والبيـرة،

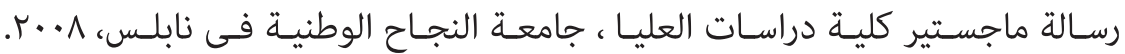
سيّيهم: كَّْار:

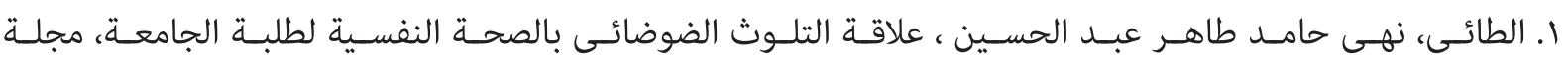

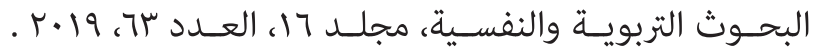
ب، البحرانسى، حسـين شـاكر محمـوود ، دراسـة حقليـة عـن آهــم مصـادر التــوث الضوضائسى فـى الآحيـاء السـكنية

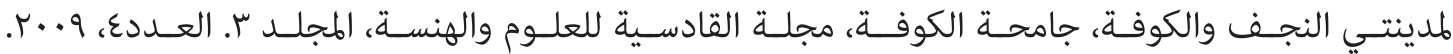

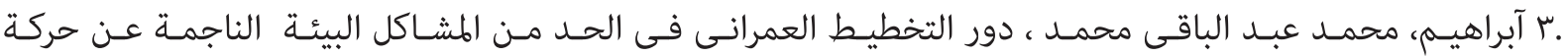

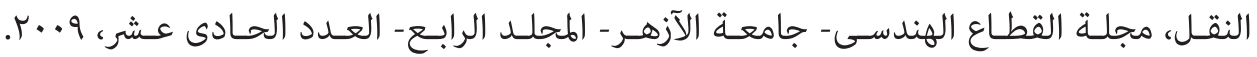

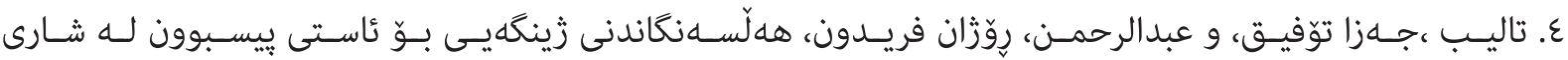

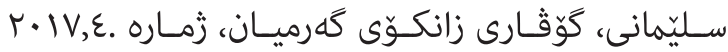
0. جمعــة، غفــران فـاروق، تقيـم التــوث بالضوصـاء فـى بعـض مــارس مدينـة بغدا،مجلــة الهندسـة والتكنولوجيـا، 


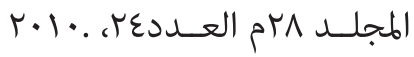

7. عبدالحسـن، هاشـم جعفـر، التــوث الضوضائسى وآثره فـى البيئـة الصحيـة للمسـتهلك، جامعـة بغــاد، مركـز بحـوث

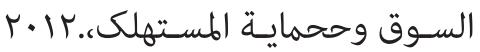

V. مـردان، عبدالرحمـن جــرى، طـارق جمعــة علـى، آسـامة حميـــ مجيـد، مسـتويات التــوث الضوضائسى فـى مدينـة

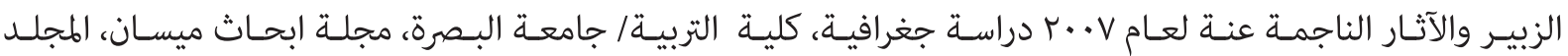

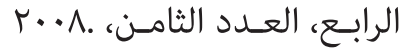

^. وارتـان، ســونيا ارزرونـى، و عبداللـه، ياســمين نجـم ، التــوث الضوضائسى فـى محافظـة البـصرة (مصادره-آثـاره-

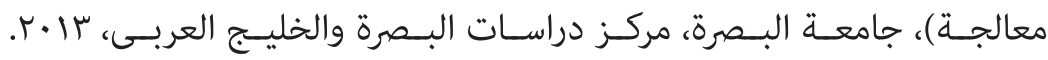

Noise:A Health Problem Office of Noise Abatement and Control, Washington, 1.,19V^,US EPA .1.

$.19 V \wedge$,August ,DCr.\&7.

Narendra, Singh, S, Davar, Noise pollution- Soureces, Efeects and control,Kurukshetra University, . II .$r \cdot \varepsilon$,Indaia, j, Ecol

Anomohanran, Ochujo, Evaluation of Environment Noise Pollution in Abuja, Physice, . Ir $r \cdot r$ February ,issuer universityAbraka, voll $1 \varepsilon$

جִوارهم: بلّاوكراوهى حكومى:

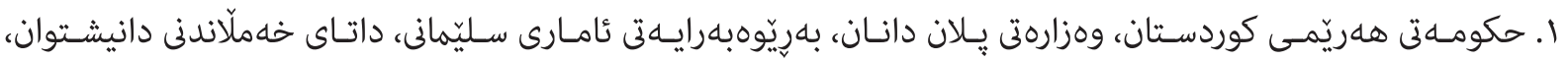

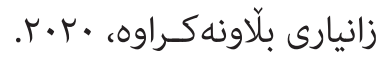
r. وزارة التخطيطط، الجهاز المركزي للاحصـاء، نتائج التعـداد العـام للسـكان لســة $19 V V$ و 9AV ا، محافظـة السـليمانية، مطبعـة الجهـاز المركـزي، بغـداد. س. مديرية احصاء السليمانية، المؤشرات السكانية والبني الخدمية والارتكازية لأقليم كوردستان العراق لسنة . . r.

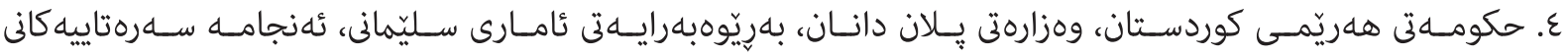

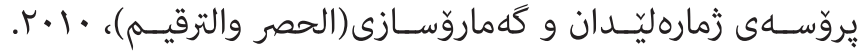

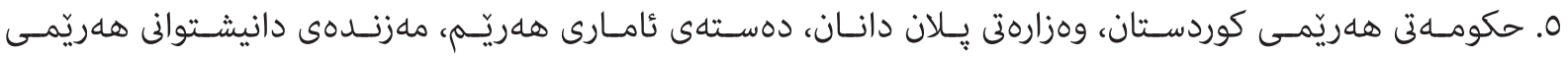

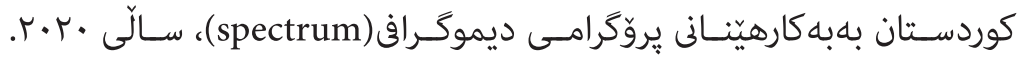

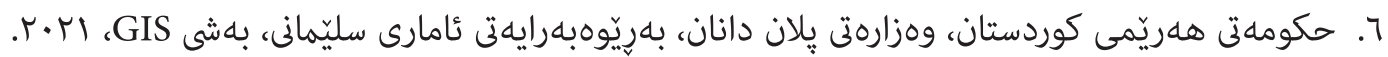

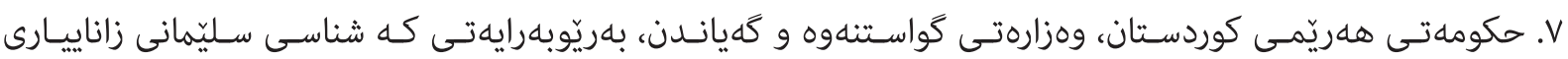
بلآونهكراوه.

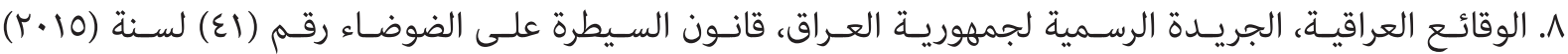
العـدد 